\title{
Rethinking the time allocation of Egyptian females: A matching analysis
}

Rana Hardy

Follow this and additional works at: https://knowledgecommons.popcouncil.org/departments_sbsr-pgy

Part of the Demography, Population, and Ecology Commons, Family, Life Course, and Society Commons, Gender and Sexuality Commons, International Public Health Commons, Labor Economics Commons, Women's Health Commons, and the Work, Economy and Organizations Commons How does access to this work benefit you? Let us know!

\section{Recommended Citation}

Hardy, Rana. 2011. "Rethinking the time allocation of Egyptian females: A matching analysis," Gender and Work in the MENA Region Working Paper no. 17. Cairo: Population Council. 


\section{NUMBER 17}

JUNE 2011

GENDER AND WORK IN THE MENA REGION

WORKING PAPER SERIES

Poverty, Job Quality and Labor Market Dynamics

Rethinking the Time Allocation

of Egyptian Females:

A Matching Analysis

Rana Hendy

(2) Population Council 
The research presented in this publication is the result of a project funded by Canada's International Development Research Centre (www.idrc.ca).

\section{IDRC * CRDI}

Canad'à

\section{(1) Population Council}

Research that makes a difference

The Population Council confronts critical health and development issues-from stopping the spread of HIV to improving reproductive health and ensuring that young people lead full and productive lives. Through biomedical, social science and public health research in 50 countries, the Council works with our partners to deliver solutions that lead to more effective policies, programs, and technologies to improve lives worldwide. Established in 1952 and headquartered in New York, the Council is a nongovernmental, nonprofit organization with an international board of trustees.

Population Council

Egypt Office

59 Misr Helwan Agricultural Road, Maadi, Cairo, Egypt

Tel.: (+202) 2525-5965, (+202) 2525-5967, (+202) 2525-5968

Facsimile: (+202) 2525-5962

Website: http://www.popcouncil.org

Email: pcouncil@popcouncil.org

(c) 2011 The Population Council, Inc.

Any part of this publication may be reproduced without permission for limited distribution, provided it is distributed without charge and the Population Council is acknowledged as its source. The Population Council would appreciate receiving a copy of any materials in which the text is used.

ISSN: 11870/2011 
NUMBER 17

JUNE 2011

GENDER AND WORK IN THE MENA REGION WORKING PAPER SERIES

Poverty, Job Quality and Labor Market Dynamics

\section{Rethinking the Time Allocation of Egyptian Females: \\ A Matching Analysis}

Rana Hendy 



\section{Table of contents}

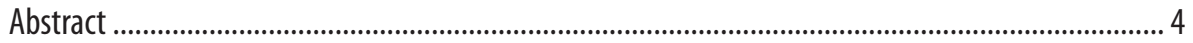

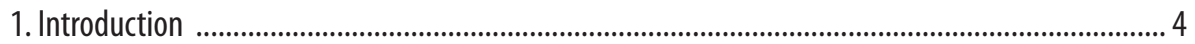

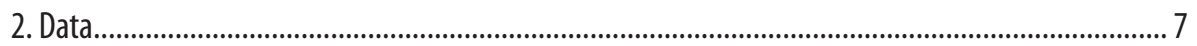

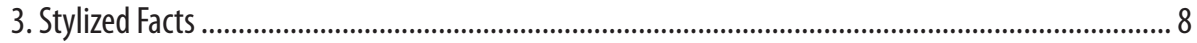

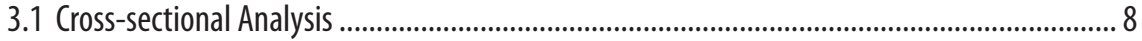

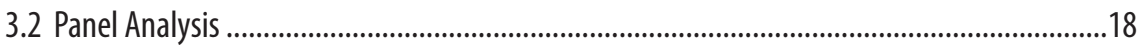

4. Propensity Score Matching Model ............................................................................................. 21

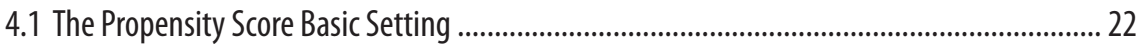

4.2 Identification of the Model ..................................................................................................... 24

4.3 The Average Treatment Effect on the Treated .................................................................... 24

5. Empirical Result ............................................................................................................ 26

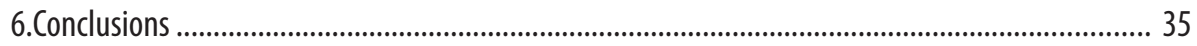

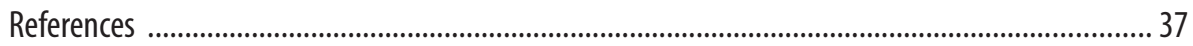

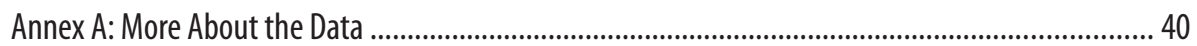

Annex B: Sensitivity Analysis .................................................................................................. 41

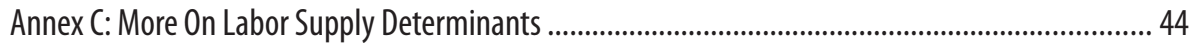




\section{Abstract}

This study explores the extremely biased division of labor within Egyptian households. The effects of marriage on women's market and domestic labor supplies are important aspects of this study. New explanations for married women's low participation rates are proposed. A matching model is estimated to determine how selection into marriage alters the time allocation of women. The empirical results show that marriage significantly affects both types of work. Married women spend weekly about eight hours less on market work relative to their single counterparts. Interestingly, marriage as a treatment increases domestic labor supply by thirty hours weekly.

JEL classification: Di3, Ji6, J22.

Keywords: Time Allocation, Marriage, Matching, Egypt.

\section{Introduction}

The classical dichotomy of "work in the market" versus "leisure" may serve as a good approximation of the role played by men in the productive activity of the household but does gross injustice to women, since it overlooks the whole time she spends outside the market on domestic activities. For this reason, studying females' invisible unpaid work is crucial.

The need to adopt the household as a unit of analysis is particulary significant if the focus of attention is women's economic behavior, as women tend to invest more time in activities that remain outside the cash economy. Economists have made a great effort to explain the market behavior of married women (i.e., patterns of participation, number of working hours, and determinants of wives earnings etc..), although very little has been done, in developing countries, to analyze the allocation of time within the home sector.

Let us start by defining "domestic production." It represents all the unpaid work done to maintain family members and/or a home. This topic has been widely recognized in developed countries as an important area of research study since the I990's. Over the last decade, increasing attention 
has been paid to the analysis of the labor division between members of the same household.

As Becker (1964) and Gronau (1976) argued, calling the whole time spent by women outside the market sector "leisure" is to underestimate her contribution to the economy and to overlook the production activities she engages in through work at home. These activities are better termed "domestic production."

According to the UN convention "all persons of either sex who furnish the supply of labor for the production of economic goods and services" should have been included in labor force statistics during the last two decades (ILO, 1976), quoted in Beneria (198I). In addition to this, economic activities, theoretically, should satisfy human needs through the production of goods and services, regardless of whether they are channeled through the cash market or other forms of exchange. There is no good reason why cooking and food processing should be considered less productive than growing food, especially that cooking for one's employer is an economic activity but cooking for one's own household is not (Waring, 1988). Adoption of such a definition would give visibility to women and children in national figures, since they make important economic contributions to both the domestic unit and to the national economy through these activities. Moreover, correct information on women's work is "crucial for diagnosing the causes of poverty and inequality and for guiding policymakers in their attempts to improve living standards" (Schaffner, 2000a).

Neoclassical theory (Becker, 1965) has convincingly argued that the division between women's participation in non-market activities and males' participation in market activities is based on efficiency and the maximization of utility. However, the latter point does not seem to be justified, since females' contribution to their household often exceeds that of males and their share of benefits is less (Folbre, I984). Moreover, while many women contribute more hours of work to support their households than their spouses do, they often declare "I do not work" or "I am only a bouserwife," because their labor is not remunerated. This has significant implications on their status and their position not only in their own households, but also in the society (Hoodfar, 1997).

As Gronau (1976) mentioned, the wife's time is an iceberg since we have plenty of information about the visible tip, the time spent in the market, but almost none about the submerged part spent at home. In other words, "the problem of females' activities is that they are often not 'counted' in statistics, not 'accounted for' in representations of the economy and not 'taken into account' when policies are created" (Elson, 2000). Suitable statistical means are 
greatly needed to recognize and make visible the full extent of women's work and all their contributions to the national economy, including their contribution to unremunerated sectors (United Nations, Fourth World Conference on Women, 1995-68.b).

An extensive literature exists on the "dilemmas" of modern family life (Gerson, 1985; Frinking and Willemsem, 1997). It has to be recognized that the division of paid and unpaid work concerns the family unit as well as the whole society since it has many socioeconomic implications.

Yet, time allocation in Egypt and in the Arab world has not been empirically studied. The present work aims at studying the allocation of time between market and domestic work to allow for better measurement and consideration of women's work. Unfortunately, data on domestic production are only available for women. Nevertheless, assuming that men do not participate in non market work does not seem to be a strong assumption in the Egyptian and Arab contexts.

As in most developing economies, female labor force participation rates in Egypt remain relatively low. At different points of time- 1988 , 1998 and 2006- over 65 percent of ever married women were not actively engaged in market production and not more than 30 percent participated in the labor market (Assaad, 2007; Assaad and El-Hamidi, 2009). In other words, the women's main occupation in Egypt remains housewives. The present research gives new evidence on the perfectly biased intrahousehold allocation of time that represents a considerable constraint for married females to reconciliate between family and professional lives. Hence, the implementation of more serious family-friendly policies calling for a more equitable division of labor within the family are strongly needed. For instance, increasing part-time jobs that take into full consideration the burden of women's household responsibilities are also crucial to enable women to continue working after marriage.

Bearing in mind these facts, several questions arise: how has domestic production changed over time especially with the decrease in fertility and increase in time-saving devices. And, how does marriage affect the timeuse of Egyptian women. The present study provides a deep descriptive analysis that aims at having alance at how Egyptian women use their time, the evolution of women's time allocation over time and, the difference between single and married women's time allocation.

Time-use profiles are constructed using the Egyptian Labor Market Panel Surveys (ELMPS) of 1998 and 2006. Unfortunately, the timeuse questionnaire is available only for women and children. As the data collectors argued, men refused to answer the questions on domestic 
activities because they think it is humiliating. For this reason, comparisons between time allocation of men and women cannot be made in this study.

In the analysis, we distinguish between single and married women. Note that, as defined in the present study, single women are those who have never been married, and married ones are those currently married and living with their spouse in the same household. All divorced and widowed women are excluded from the analysis.

This paper first provides a cross-sectional analysis that aims at exploring Egyptian women's time-use among different work categories in 2006. Then, using both surveys from 1998 and 2006, I make use of the panel aspect of the data in order to observe differences in women's timeuse that result from changes in their marital status. Finally, a matching model is estimated to identify how selection into marriage alters the time allocation of women.

In the analysis, I distinguish between three main work categories. (I) 'market work' encompasses all activities that produce goods and services that contribute to national wealth and economic growth (Donahoe, 1999). The latter includes all market and subsistence activities whether paid monetarily, in kind, or unpaid work for family. This type of work is common in most developing countries. (2) 'domestic work' involves all unpaid work done to maintain family members and/or a home. It includes housework and child care activities (see Appendix A for more details). Finally, (3) 'total work' regroups these two working activities to account for the total time spent per week in all types of work. Typically, subtracting the latter from the total weekly time available for individuals ( 24 hours multiplied by seven days, or I68 hours per week) would allow the calculation of the amount of hours per week available for leisure activities.

The paper is organized as follows: section 2 is devoted to the presentation of the data. Section 3 displays the descriptive analysis using a cross sectional as well as a panel approach. Section 4 presents the matching model specifications. Section 5 shows the empirical results and, section 6 concludes.

\section{Data}

Data used in this study are obtained from the nationally-representative Egyptian Labor Market Panel Surveys (ELMPS) of 1998 and 2006. Of the $8,37 \mathrm{I}$ households interviewed in 2006, 3,701 were households that were interviewed in ELMS 1998, 2,I67 were splits from the original 
households, and 2,498 were part of an entirely new refresher sample. In total, 17,364 individuals were successfully tracked from 1998 to 2006. These households were selected from a CAPMAS (Central Agency for Public Mobilizations and Statistics) master sample prepared in 1995. The questionnaire is composed of three major sections: (I) a household questionnaire administered to the head of household or the head's spouse that contains information on basic demographic characteristics of household members, movement of household members in and out of the household since 1998, ownership of durable goods and assets, and housing conditions, (2) an individual questionnaire administered to the individual him or herself containing information on parental background, detailed education histories, activity status, job search and unemployment, detailed employment characteristics, a module on women's work, migration histories, job histories, time-use, earnings and fertility. (3) a household enterprise and income module that elicits information on all agricultural and non-agricultural enterprises operated by the household as well as all income sources, including remittances and transfers (Barsoum, 2007).

The ELMPS is the first panel data available in the Arab region and is known for its richness, which allows economists to closely study various issues related to the Egyptian labor market. In the present study, all women aged between 16 and 64 are considered. The analysis of domestic production activities is based on a specific question: how did you spend the preceding week. In the data, domestic activities were classified into I4 groups (see Appendix A for more details). However, for the 1998 survey, only three aggregated questions are available. For this reason, in the following section, I conduct the cross sectional analysis using only the 2006 survey since this is able to reflect the real time that women spend in domestic activities. In addition, a panel analysis is conducted using all women who were single in 1998 and changed (or not) their marital status between I998 and 2006. In the panel analysis, the sample consists of I,850 women.

\section{Stylized Facts}

\subsection{Cross-sectional Analysis}

Table I shows the time-use of women and men by marital status in 2006. All numbers showed in this table are weekly mean hours. Egyptian married women spend weekly, on average, 46.72 hours on domestic chores. Turning our attention to market labor supply, men spend longer hours on market 
activities than women, and this does not seem to differ among married and unmarried men. Contrary to men, single women spend longer hours in the market than married women do, at 43.86 and 37.34 hours, respectively. Also, single and married women spend 19.09 and 46.72 hours respectively on 'work at home' activities. Note that the 'work at home' category is composed of housework activities as well as child care activities. Total work is calculated as the sum of hours spent on both market and domestic activities. Interestingly, the latter is higher for women than for men whether they are married or single. As shown in Table I, for the married population, 84.04 and 50.92 hours among women and men, respectively, are spent on total work. Again, men are assumed to not participate at all in domestic activities, which is not a strong assumption for the Egyptian context. Finally, leisure is calculated as the difference between the total time available per week and the time spent on total work.

Table 1: Time-use by gender and marital status in 2006

\begin{tabular}{|l|c|c|c|c|}
\hline & \multicolumn{2}{|c|}{ Women } & \multicolumn{2}{c|}{ Men } \\
\hline $\begin{array}{l}\text { Time-use } \\
\text { (Mean hours) }\end{array}$ & Married & Not married & Married & Not married \\
\hline Work at home & 46.72 & 19.09 & - & - \\
\hline Housework & 37.15 & 18.58 & - & - \\
\hline Child care & 9.57 & 0.51 & - & - \\
\hline $\begin{array}{l}\text { Work in the } \\
\text { market }\end{array}$ & 37.34 & 43.86 & 50.92 & 50.01 \\
\hline Total work & 84.04 & 62.95 & 50,92 & 50,01 \\
\hline Leisure & 27.96 & 49.05 & 61,08 & 61,99 \\
\hline
\end{tabular}

Notes: i. - means that this information is not available in the ELMPS 2006.

ii. Total work represents the sum of all time spent on work in the market and work at home.

iii. Leisure is calculated as the difference between total time available per week (24-8 "time for sleeping" multiplied by 7) and the time spent on total work.

Source: Author's calculations using the ELMPS of 2006.

Table 2 displays the time allocation of both single and married taking into account the presence or not of children in the household. It shows that married women having children spend the greatest amount of hours on domestic work, at 51.72 hours per week. They spend about 20 hours more on domestic activities compared to women without children and 30 hours more compared to single women. Marriage increases dramatically 
the time spent on housework activities; the number of hours is 19.97 and 31.74 respectively for singles and married women without children. Married women with children remain the most productive, with a weekly time spent on total work of 60.98 hours.

Table 2: Time-use of all women: Sample means by marital status and the presence of children in the household*

\begin{tabular}{|l|c|c|c|c|}
\hline \multicolumn{1}{|c|}{ Time-use * } & Single & Married & Married & All \\
\hline & & without children & with children & \\
\hline Market work & 8.87 & 7.56 & 9.26 & 8.83 \\
\hline Domestic work & 20.84 & 32.58 & 51.72 & 37.53 \\
\hline Housework & 19.97 & 31.74 & 38.86 & 30.97 \\
\hline Child care & 0.87 & 0.84 & 12.86 & 6.56 \\
\hline Total work & 29.71 & 40.14 & 60.98 & 46.36 \\
\hline N & 4103 & 2000 & 5526 & 11629 \\
\hline
\end{tabular}

Note: ${ }^{*}$ This table shows women's time-use using weekly hours of work.

Source: Author's calculations using the ELMPS of 2006.

Table 3 displays women's time allocation by marital status and age group. Interestingly, regardless of the age group, single and married women spend a similar number of hours on market activities. However, married women in general tend to spend longer hours on domestic activities than their single counterparts do. For instance, for the 16-35 age group, married and single women spend on average 32.05 and $18.9 \mathrm{I}$ hours respectively on domestic activities. Consequently, for all age groups, the 'total work' category is significantly greater for married than for single women. Turning our attention to the 46-64 age group, married and single women spend $40.9 \mathrm{I}$ and 31.75 hours respectively on total work. Similarly, married and single women aged between $\mathrm{I} 6$ and 35 spend 37.54 and 26.80 respectively. However, there is no difference in total work for the $36^{-} 45$ age group. To put it in a nutshell, married women do not work less in the market but do work much more at home than single women do.

Table 3: Time-use of all women: sample means by marital status and age group

\begin{tabular}{|c|c|c|c|c|c|c|}
\hline Time-use & \multicolumn{3}{|c|}{ Single } & \multicolumn{3}{c|}{ Married } \\
\hline & $16-35$ & $36-45$ & $46-64$ & $16-35$ & $36-45$ & $46-64$ \\
\hline
\end{tabular}




\begin{tabular}{|l|c|c|c|c|c|c|}
\hline Market work & 7.89 & 19.26 & 8.81 & 5.49 & 18.31 & 8.05 \\
\hline Domestic work & 18.91 & 34.49 & 22.94 & 32.05 & 32.28 & 32.86 \\
\hline Housework & 18.28 & 31.35 & 21.99 & 31.92 & 32.03 & 31.64 \\
\hline Child care & 0.63 & 3.14 & 0.95 & 0.12 & 0.25 & 1.22 \\
\hline Total work & 26.80 & 53.75 & 31.75 & 37.54 & 50.59 & 40.91 \\
\hline $\mathrm{N}$ & 2954 & 284 & 865 & 640 & 65 & 1295 \\
\hline
\end{tabular}

Source: Author's calculations using the ELMPS of 2006.

Table 4 presents married women's time allocation by the presence of children in the household and by age group. For the $36-45$ age group, we observe that the presence of children decreases time spent on market work by five hours. This is the result of child care activities that increase significantly with the presence of children. Thus, children largely influence women's total work; 60.85 hours for those with children and 50.59 hours for women without children. In Table 4 , women with and without children aged between $\mathrm{I} 6$ and 35 spend 62.30 and 37.54 hours on total work respectively. This is also valid for the other age groups. To conclude, both marriage and fertility are important factors affecting both market and domestic labor supply.

Table 4: Time-use of married women: Sample means by presence of children and age group

\begin{tabular}{|l|c|c|c|c|}
\hline Married without children & & Age 16-35 & Age 36-45 & Age 46-64 \\
\hline & Market work & 5.49 & 18.31 & 8.05 \\
\hline & Domestic work & 32.05 & 32.28 & 32.86 \\
\hline & Housework & 31.92 & 32.03 & 31.64 \\
\hline & Child care & 0.12 & 0.25 & 1.22 \\
\hline & Total work & 37.54 & 50.59 & 40.91 \\
\hline Married with children & N & 640 & 65 & 1295 \\
\hline & & & & \\
\hline & Market work & 6.46 & 13.83 & 13.11 \\
\hline & Domestic work & 55.84 & 47.02 & 39.42 \\
\hline & Housework & 38.98 & 39.24 & 36.80 \\
\hline
\end{tabular}




\begin{tabular}{|c|c|c|c|c|}
\hline & Child care & 16.86 & 7.77 & 2.62 \\
\hline & Total work & 62.30 & 60.85 & 52.53 \\
\hline & $\mathrm{N}$ & 3379 & 1645 & 502 \\
\hline
\end{tabular}

Source: Author's calculations using the ELMPS of 2006.

Table 5 presents the time allocation of married women by number of children. It mainly distinguishes between three types of married women: those who don't have children, those who have only one child and those who have two children or more. It is worth noting that the first child is the one who affects the mothers' time-use patterns the most. As shown in Table 5, the arrival of the first child increases the time spent on domestic activities by more than 20 hours (from 32.74 to 53.9I) and decreases by only one hour, on average, the time spent in the labor market. This is mainly due to a significant increase in the time spent on child care activities. Similarly, the time spent on total work for married women without children and married women with one child is 40.35 and 60.34 respectively.

Table 5: Time-use of married women: Sample means by the number of children

\begin{tabular}{|l|c|c|c|c|}
\hline & \multicolumn{3}{|c|}{ Number of children } & \\
\hline Time-use & Zero & One & Two or more & Total \\
\hline Market work & 7.61 & 6.43 & 10.08 & 8.83 \\
\hline Domestic work & 32.74 & 53.91 & 51.15 & 46.72 \\
\hline Housework & 31.9 & 36.23 & 39.65 & 37.04 \\
\hline Child care & 0.84 & 17.68 & 11.49 & 9.68 \\
\hline Total work & 40.35 & 60.34 & 61.23 & 55.5 \\
\hline N & 1989 & 1229 & 4293 & 7511 \\
\hline
\end{tabular}

Source: Author's calculations using the ELMPS of 2006.

Table 6 shows working women's time allocation by economic sector. It reveals that, in general, women working in the private sector work for longer hours than both women who work in the public sector and independent workers. Turning our attention to single females, these women spend 4I.II, 54.27 and 36.99 hours in the public, private and the independent sectors respectively. Furthermore, 70.34 percent of all women working in the private sector are single. Compared to married women, single women spend longer hours in the private sector. However, public sector labor supply is similar for all women. In addition, the presence of children in the household decreases, as expected, both public and 
private employment. Table 6 also shows that 59.68 percent of all women working in the public sector are married and have children. This is thanks to the flexibility of working hours and the family-friendly policies in the public sector. Concerning the independent sector, single, married women without children and married women with children spend 36.99, 3I.43 and 32.89 hours respectively. Although the independent sector is dominated by married women, as will be shown later, having a family project increases female market labor supply. Generally, the owners of the family project are members of the same household. Finally, only 31.83, I5.68 and 52.49 percent of single women, women married without children and women married with children, respectively, are working in the labor market.

Table 6: Time-use of all women: Sample means by marital status, presence of children and working sector (working women only)

\begin{tabular}{|l|c|c|c|c|}
\hline & Single & Married & Married & All \\
\hline Public & $41.11(23.3 \%)$ & $41.41(17.03 \%)$ & $40.55(59.68 \%)$ & $37.72(100 \%)$ \\
\hline Government & 40.93 & 41.16 & 40.42 & \\
\hline $\begin{array}{l}\text { Public } \\
\text { enterprises }\end{array}$ & 42.84 & 44.92 & 43.25 & \\
\hline Private & $\begin{array}{c}54.27 \\
(70.34 \%)\end{array}$ & $47.12(6.3 \%)$ & $43.2(23.36 \%)$ & $51.70(100 \%)$ \\
\hline Formal & 51.09 & 45.15 & 44.7 & \\
\hline Informal & 55.93 & 49.45 & 45.84 & \\
\hline Independent & $\begin{array}{c}36.99 \\
(27.23 \%)\end{array}$ & $\begin{array}{c}31.43 \\
(17.58 \%)\end{array}$ & $\begin{array}{c}32.89 \\
(55.18 \%)\end{array}$ & $33.75(100 \%)$ \\
\hline $\mathrm{N}$ & $830(31.83 \%)$ & $409(15.68 \%)$ & $1369(52.49 \%)$ & $2608(100 \%)$ \\
\hline
\end{tabular}

Source: Author's calculations using the ELMPS of 2006.

Table 7 displays married women's time allocation by level of education. Interestingly, we observe that the higher the level of education the greater is women's total work. More precisely, women who are illiterate, less than intermediatly educated, intermediately educated and have an above intermediate education spend, respectively, 49.65, 51.37, 60.85 and 65.67 hours on total work. Note that the time spent on child care activities increases with the level of education. Moreover, women with an intermediate education or above have higher market labor supply than those with a less than intermediate education. Consequently, as shown in Table 7 , increasing married women's level of education implies an increase 
in the time spent on both total work and child care activities, and decreases the time spent on housework activities.

Table 7: Time-use of married momen: Sample means by level of education

\begin{tabular}{|c|c|c|c|c|c|}
\hline & & Level of & ducation & & \\
\hline & Illiterate & $\begin{array}{c}\text { Less than } \\
\text { intermediate }\end{array}$ & Intermediate & $\begin{array}{c}\text { Above } \\
\text { intermediate }\end{array}$ & Total \\
\hline Age & 40.17 & 34.78 & 31.36 & 33.99 & 36 \\
\hline Time-use & & & & & \\
\hline $\begin{array}{l}\text { Market } \\
\text { work }\end{array}$ & 6.68 & 3.14 & 9.79 & 17.66 & 8.83 \\
\hline $\begin{array}{l}\text { Domestic } \\
\text { work }\end{array}$ & 42.97 & 48.23 & 51.06 & 48.01 & 46.72 \\
\hline Housework & 36.42 & 38.51 & 37.87 & 36.08 & 37.04 \\
\hline Child care & 6.55 & 9.72 & 13.18 & 11.94 & 9.68 \\
\hline Total work & 49.65 & 51.37 & 60.85 & 65.67 & 55.5 \\
\hline $\mathrm{N}$ & 3241 & 955 & 2146 & 1167 & 7511 \\
\hline
\end{tabular}

Source: Author's calculations using the ELMPS of 2006.

Table 8 shows, for single women, the same information available in Table 7. Single women with high levels of education spend between five and ten hours less on domestic activities than illiterate single women. Women with an above intermediate education also have higher market labor supply than less educated ones. Interestingly, illiterate single women spend longer hours in total work than women with a less than intermediate or an intermediate education. This result was expected since working, for illiterate women, is an absolute necessity. Nevertheless, those having an above than intermediate education are those who work the most since they spend 4I.OI hours on all activities compared to 34.79, 20.04 and 29.07 among those who are illiterate, have less than intermediate education and have an intermediate education, respectively

Table 8: Time-use of single women: Sample means by level of education

\begin{tabular}{|l|c|c|c|c|c|}
\hline & \multicolumn{5}{|c|}{ Level of education } \\
\hline & Illiterate & $\begin{array}{c}\text { Less than } \\
\text { intermediate }\end{array}$ & Intermediate & Above & Total \\
\hline Age & 42.73 & 22.45 & 23.05 & 28.02 & 29.41 \\
\hline
\end{tabular}




\begin{tabular}{|l|c|c|c|c|c|}
\hline Time-use & & & & & \\
\hline Market work & 8.73 & 3.77 & 9.02 & 19.66 & 8.97 \\
\hline Domestic work & 26.06 & 16.27 & 20.05 & 21.35 & 21.05 \\
\hline Housework & 24.76 & 15.70 & 19.20 & 20.73 & 20.17 \\
\hline Child care & 1.29 & 0.56 & 0.85 & 0.62 & 0.88 \\
\hline Total work & 34.79 & 20.04 & 29.07 & 41.01 & 30.02 \\
\hline N & 1211 & 1026 & 1296 & 522 & 4056 \\
\hline
\end{tabular}

Source: Author's calculations using the ELMPS of 2006.

More detailed results on women's time allocation by marital status are presented in Figures I, 2, 3, 4, 5, and 6. Clearly, as shown in Figure I, the hours spent on domestic activities are significantly higher for married women than for single ones. However, married and single women spend similar amounts of time on market employment.

Figure 1: Time allocation by marital status

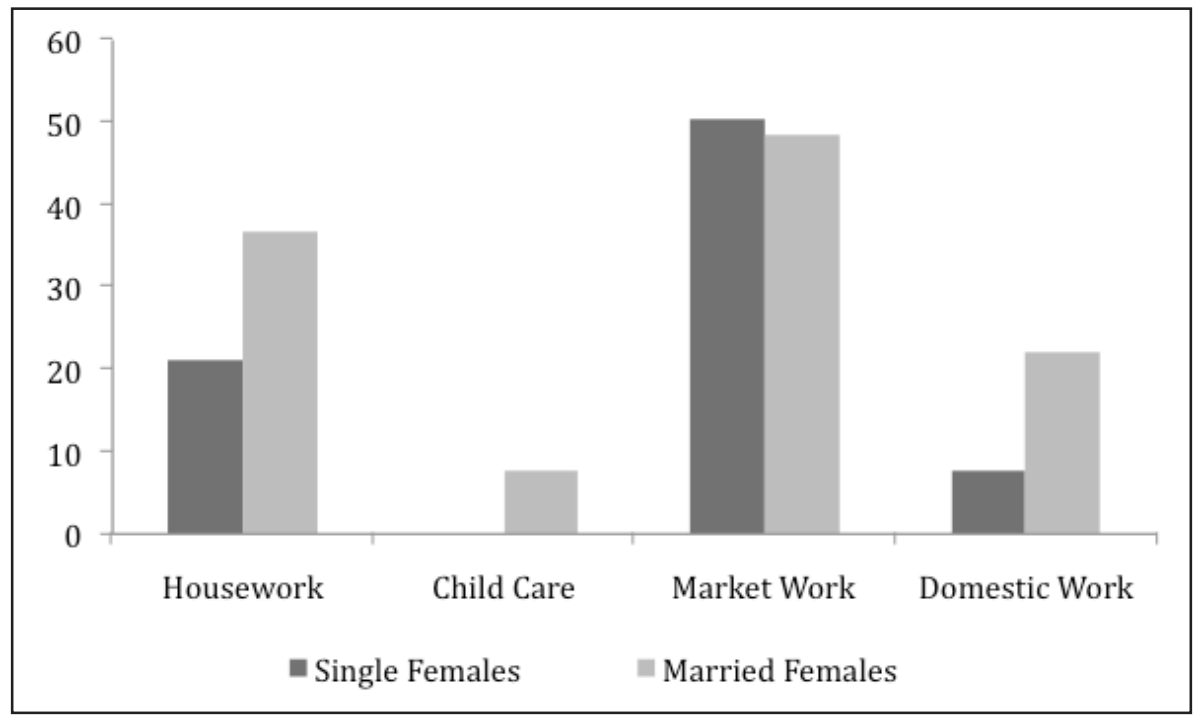

Source: Constructed by the author using the ELMPS 2006.

Figure 2 displays the results for all illiterate women. They spend longer hours on both domestic and market activities. As mentioned above, this result is in line with expectations. 
Figure 2: Time allocation by marital status: Illiterate wom

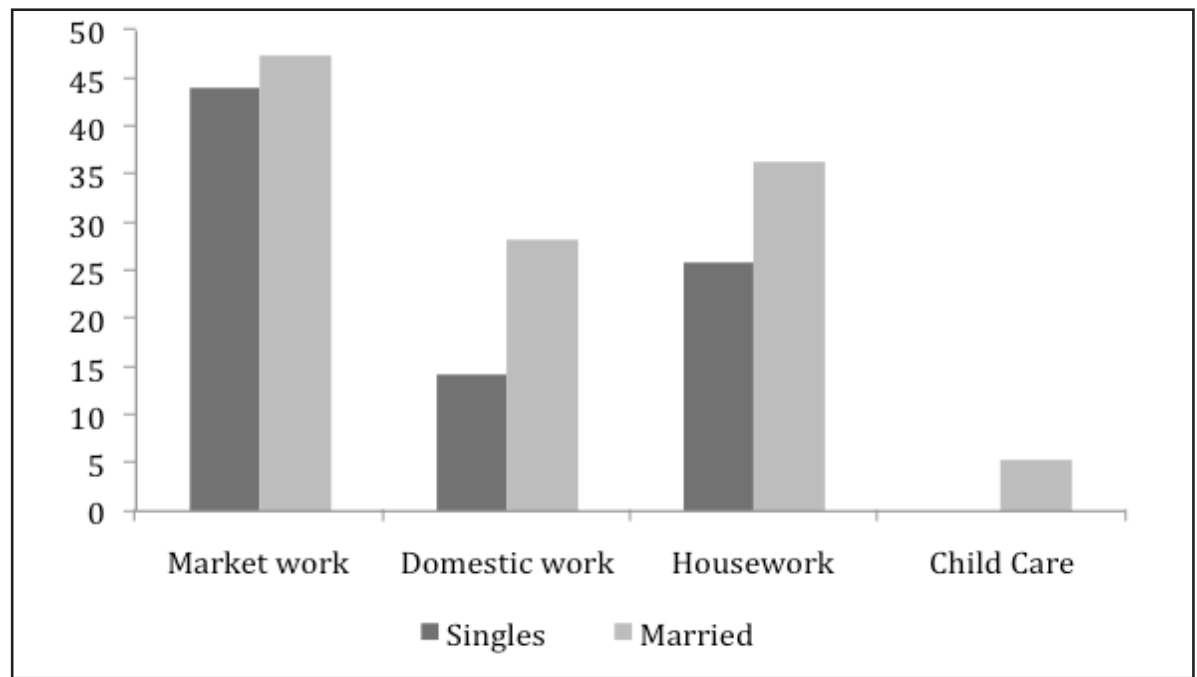

Source: Constructed by the author using the ELMPS 2006.

Figures 3 and 4 present the difference between women with general and technical intermediate education. Interestingly, married women's time allocation changes dramatically across the two figures. Among women with a general education, married women's market labor supply is higher than single women's. In contrast, Figure 4 shows that for the population with a technical education, single women are those who spend longer hours in the labor market.

Figure 3: Time allocation by marital status: Women with eneral intermediate education

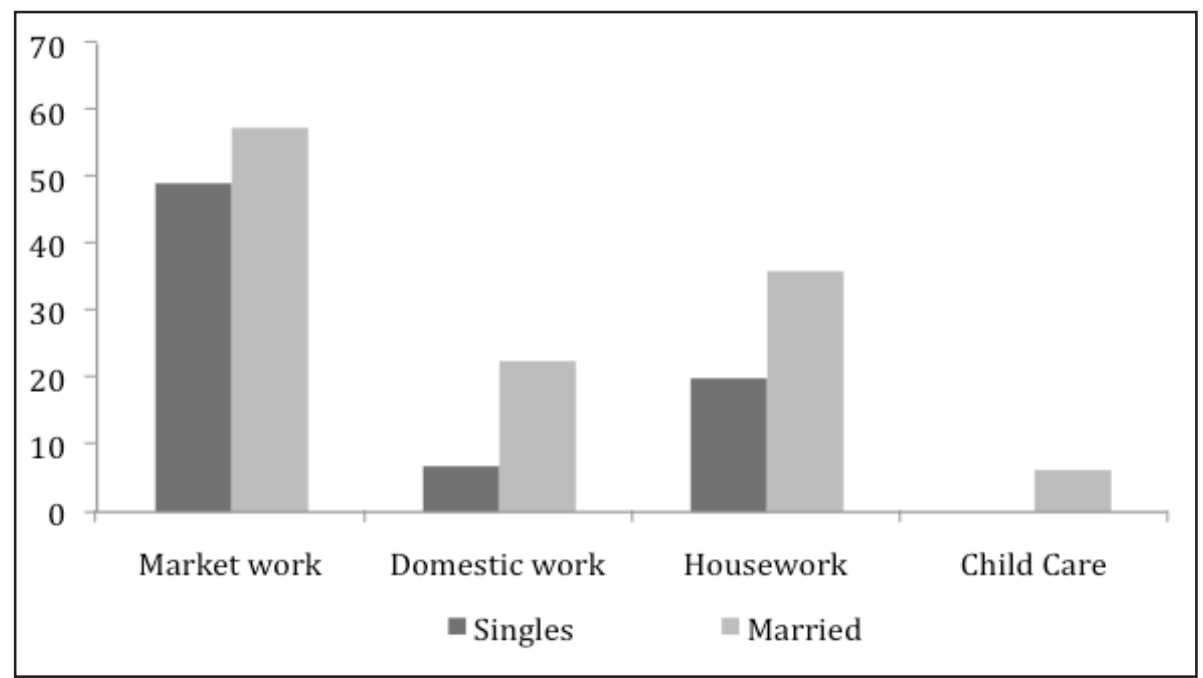

Source: Constructed by the author using the ELMPS 2006. 
Figure 4: Time allocation by marital status: Women with technical intermediate education

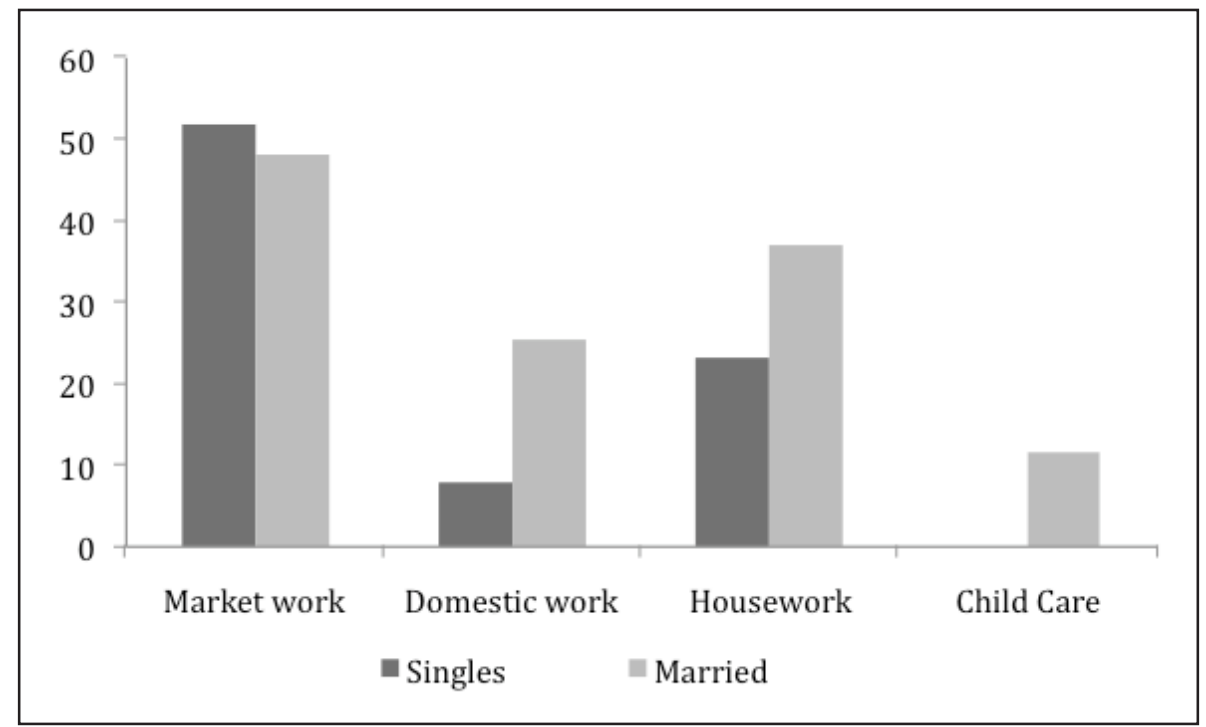

Source: Constructed by the author using the ELMPS 2006.

Finally, for women with an above intermediate or university education, Figures 5 and 6 show similar results. Generally, single women work more in the labor market and less in domestic activities than married ones.

Figure 5: Time allocation by marital status: Women with above intermediate education

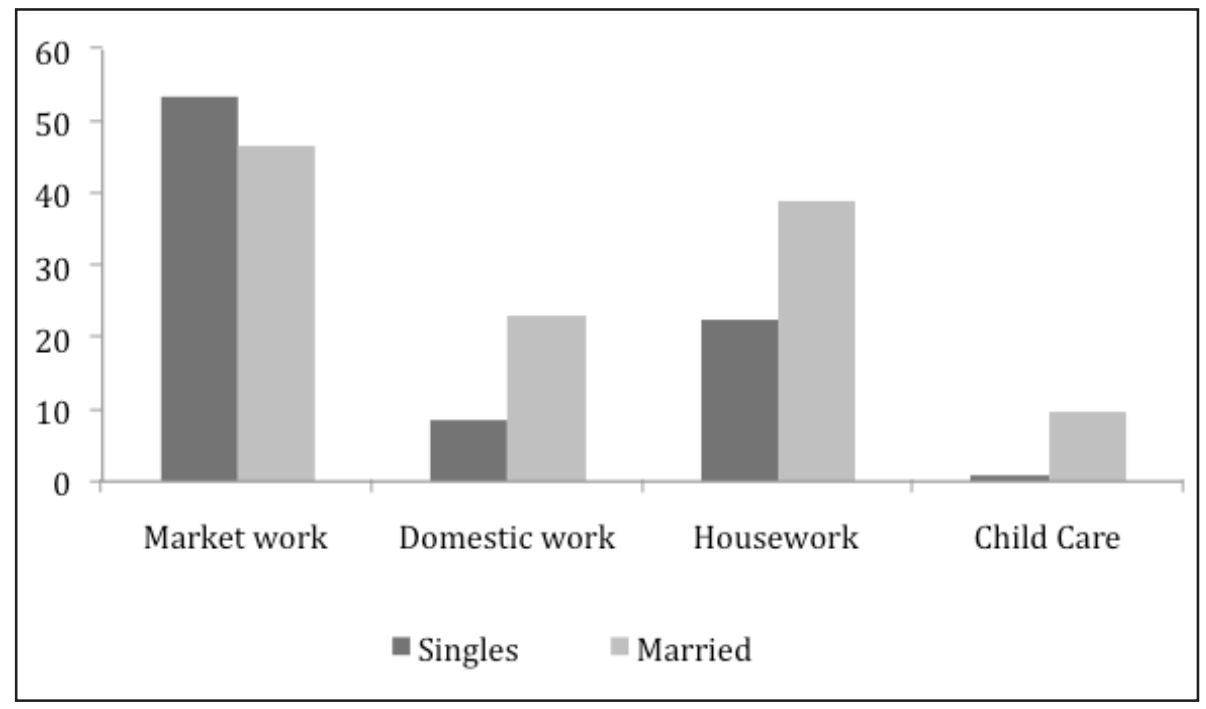

Source: Constructed by the author using the ELMPS 2006. 
Figure 6: Time allocation by marital status: University educated women

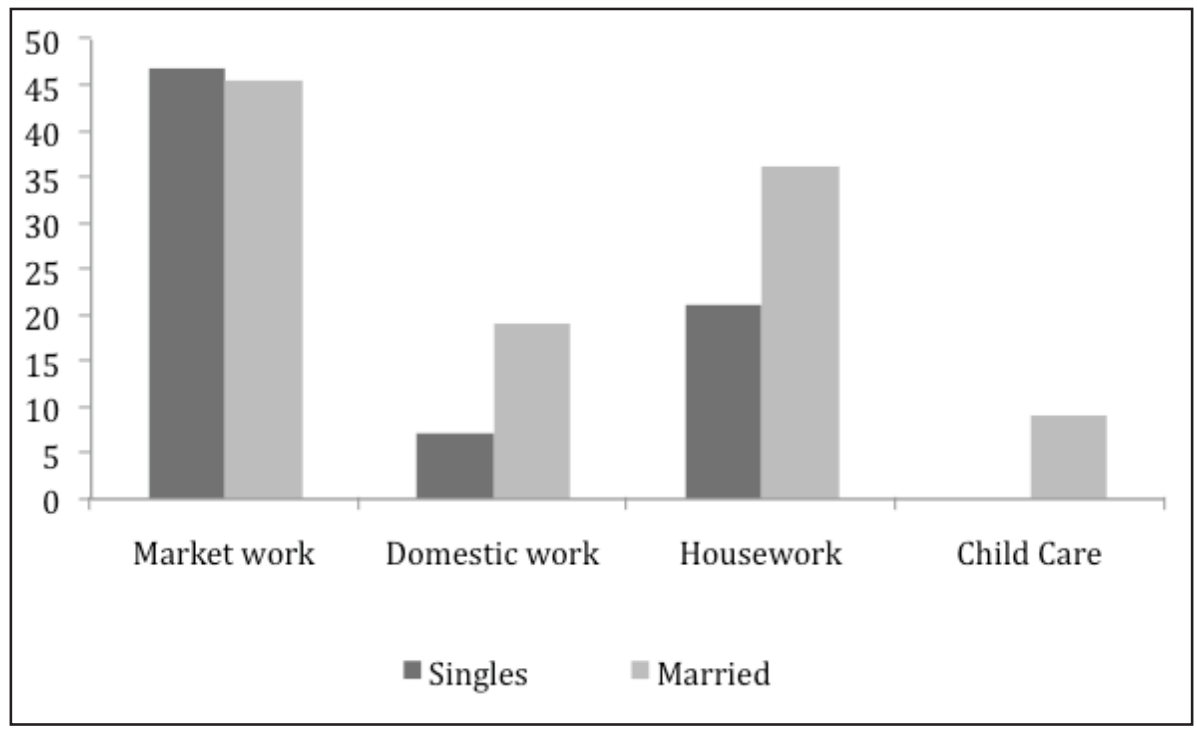

Source: Constructed by the author using the ELMPS 2006.

\subsection{Panel Analysis}

This section aims to understand how women's time allocation changes over time as they transition into marriage. To address this issue, I rely on the panel component of the ELMPS of 1998 and 2006. The sample I use consists of all women that were single in 1998 and did or did not change their marital status before 2006. The working sample is then restricted to single women aged 13 to 35 years in 1998 , noting that the legal age of marriage in Egypt is I6. The final sample contains I,I44 women. In the panel analysis, I compare the time allocation of women who remained single during the entire eight-year period to those who got married between 1998 and 2006.

Figures 7 and 8 display the evolution of women's time allocation, by age group, from 1998 to 2006 respectively for women who did and did not change their marital status within this eight-year period. Figure 7 presents the time allocation of women who got married between 1998 and 2006. In other words, all women represented in Figure 7 were single in I998 and married in 2006. Time allocation seems to change dramatically with marriage. Clearly, the time spent on domestic activities became significantly higher after marriage. For the 26-39 age group, domestic labor supply grew from 2I hours to 52 hours weekly in 1998 and 2006, respectively. Turning our attention to market labor supply, women work 
less when they are married than when single. This observation is in line with our expectations, since marriage creates the double burden issue that prevents women from spending long hours in the labor market.

Figure 7: Time allocation evolution of newly married women by age group

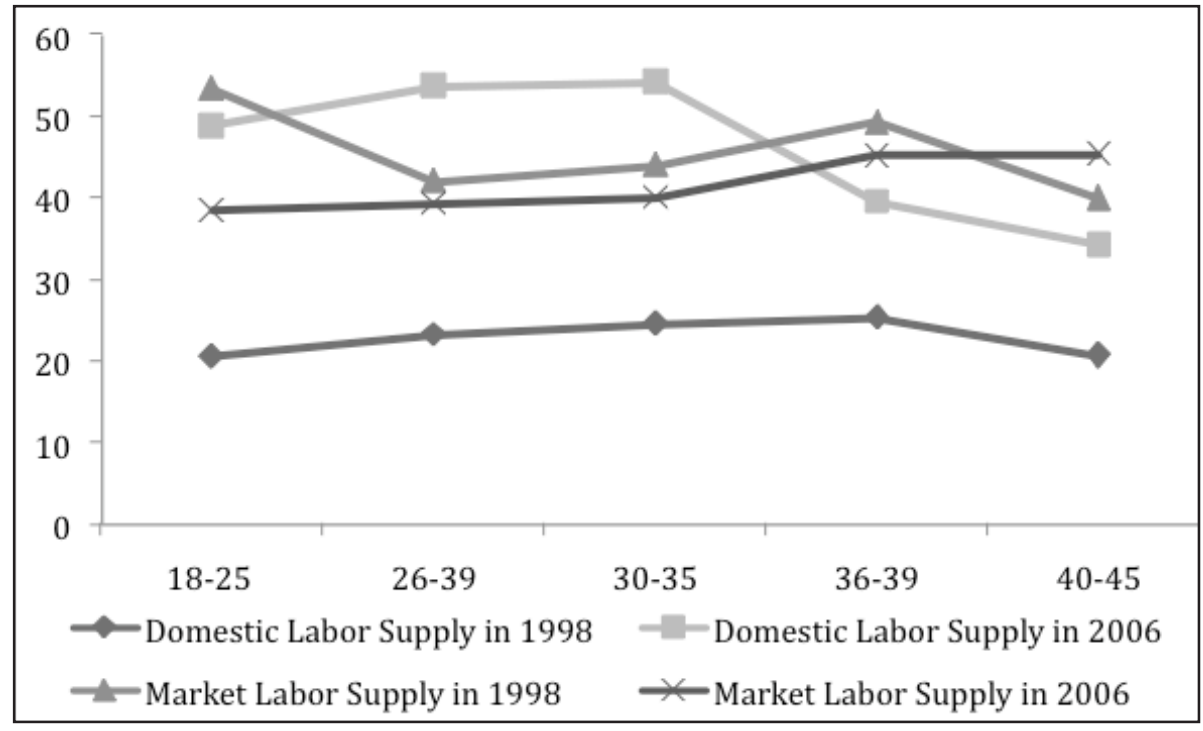

Note: Women presented in this figure are those who changed their marital status to become married between 1998 and 2006.

Source: Constructed by the author using the ELMPS of 1998 and 2006.

Similarly, in Figure 8, we observe women that remained single between 1998 and 2006. For all age groups, both domestic and market labor supply are similar in 1998 and 2006 . Thus, keeping the same marital status avoids big changes in employment patterns. All single women spend between I5 and 30 hours per week on domestic activities. The number of hours tend to increase with age, as the $4 \mathrm{O}^{-} 45$ year old women spend the longer hours compared to the younger groups. Also, market labor supply is higher for women aged 30 years old and above in 2006 than in 1998. Notably, the reason for this is that, with age, single women become more and more discouraged about finding a partner in the marriage market. 
Figure 8: Time allocation evolution of women who remained single by age group

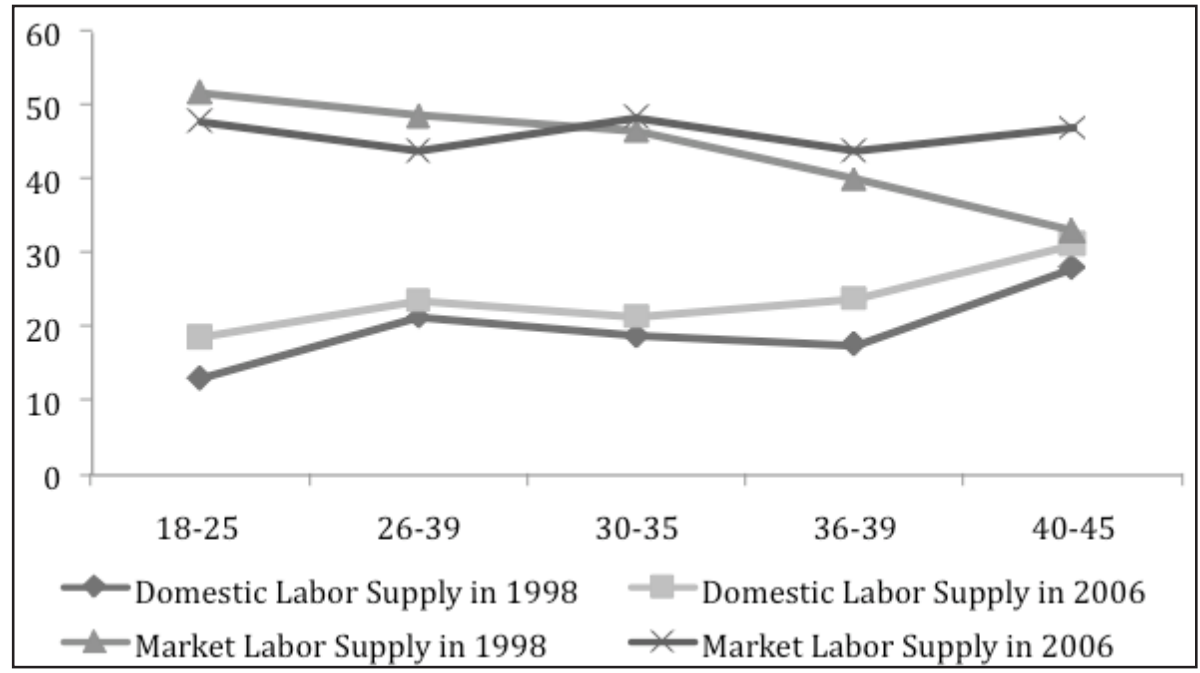

Note:Women presented in this figure are those who did not change their marital status between 1998 and 2006. Source: Constructed by the author using the ELMPS of 1998 and 2006.

Table 9 displays women's transitions into and out of market activity by marital status. Interestingly, for single and married women, respectively, 75.64 and only 40.4 percent of those who were working in 1998 continue to participate in market activities in 2006. Furthermore, 59.60 percent of women who got married between 1998 and 2006 dropped out of the labor force by 2006 , relative to only 24.36 percent among their single counterparts. Thus, Table 9 shows important transitions from market activity to inactivity as a result of marriage. Again, marriage seems to significantly increase the probability of exiting the labor market.

Table 9: Employment transitions between 1998 and 2006 by marital status

\begin{tabular}{|l|c|c|c|c|c|c|}
\hline & \multicolumn{5}{|c|}{ Market work in 2006 } \\
\hline & \multicolumn{3}{|c|}{ Single } & \multicolumn{3}{c|}{ Married } \\
\hline $\begin{array}{l}\text { Market work } \\
\text { in 1998 }\end{array}$ & No & Yes & Total & No & Yes & Total \\
\hline No & 285 & 106 & 391 & 500 & 76 & 576 \\
\hline & 72,89 & 27,11 & 100 & 86,81 & 13,19 & 100 \\
\hline Yes & 19 & 59 & 78 & 59 & 40 & 99 \\
\hline & 24,36 & 75,64 & 100 & 59,6 & 40,4 & 100 \\
\hline
\end{tabular}




\begin{tabular}{|l|c|c|c|c|c|c|}
\hline Total & 304 & 165 & 469 & 559 & 116 & 675 \\
\hline & 64,82 & 35,18 & 100 & 82,81 & 17,19 & 100 \\
\hline
\end{tabular}

Note: All females were single in 1998.

Source: Author's calculations using the panel sample 1998-2006.

Turning our attention to the evolution of domestic labor supply between 1998 and 2006, we see that, not surprisingly, IOo percent of married women were engaged in domestic activities in 2006.

Table 10: Transitions from/into domestic activities by marital status in 2006

\begin{tabular}{|l|c|c|c|c|c|c|}
\hline & \multicolumn{5}{|c|}{ Single } & \multicolumn{3}{c|}{ Married } \\
\hline & \multicolumn{3}{|c|}{ Yomestic work in 2006 } \\
\hline $\begin{array}{l}\text { Domestic } \\
\text { work } \\
\text { in 1998 }\end{array}$ & No & Total & No & Yes & Total \\
\hline No & $\begin{array}{c}21 \\
(13,64 \%)\end{array}$ & $\begin{array}{c}133 \\
(86,36 \%)\end{array}$ & $\begin{array}{c}154 \\
(100 \%)\end{array}$ & $0(0 \%)$ & $\begin{array}{c}142 \\
(100 \%)\end{array}$ & $\begin{array}{c}142 \\
(100 \%)\end{array}$ \\
\hline Yes & $\begin{array}{c}27 \\
(8,57 \%)\end{array}$ & $\begin{array}{c}288 \\
(91,43 \%)\end{array}$ & $\begin{array}{c}315 \\
(100 \%)\end{array}$ & $0(0 \%)$ & $\begin{array}{c}533 \\
(100 \%)\end{array}$ & $\begin{array}{c}533 \\
(100 \%)\end{array}$ \\
\hline Total & 48 & 421 & $\begin{array}{c}469 \\
(100 \%)\end{array}$ & $0(0 \%)$ & $\begin{array}{c}675 \\
(100 \%)\end{array}$ & $\begin{array}{c}675 \\
(100 \%)\end{array}$ \\
\hline
\end{tabular}

Note: All females were single in 1998.

Source: Author's calculations using the panel sample 1998-2006.

Both the cross-sectional and panel analyses presented above illustrated that women who transitioned into marriage were less likely to pursue market work and, were also more likely to be involved in domestic activities than their unmarried peers.

\section{Propensity Score Matching Model}

The main objective of this section is to measure the Average Treatment Effect on the Treated (ATT) where the treatment is getting married between 1998 and 2006. For this, a propensity score matching model is estimated to identify how selection into marriage alters the time allocation of women. 


\subsection{The Propensity Score Basic Setting}

Rosenbaum and Rubin (1983) proposed propensity score matching as a method to reduce bias in the estimation of treatment effects with observational data sets. This method has become increasingly popular, particularly in the evaluation of economic policy interventions.

The propensity score method is a popular inexact matching method. Rather than matching on the regressors, it matches on the propensity score. Propensity score matching does not require a unique match, which is a major advantage compared to exact matching, since households with no exact match do not have to be excluded. In this way, we prevent regression to the mean by matching based on a distance measure (the distance is then the difference in propensity).

When treatment is not by random assignment but depends stochastically on a vector of observable variables $X_{i}$, as in observational data, or when the treatment is targeted to some population defined by some observable characteristics (such as age, sex, or socioeconomic status), then the concept of propensity scores is useful. This is a conditional probability measure of treatment participation given $X_{i}$ and is denoted $p\left(X_{i}\right)$ (Cameron and Trivedi; 2005).

By definition, the assignment of subjects to the treatment and control groups in observational studies is not random. Therefore, there is no direct counterpart of the ATT. Hence, the estimation of the effect of the treatment may be biased by the existence of confounding factors. In other words, the counterfactual is not identified. As a substitute, following Rosenbaum and Rubin (1983), we may obtain data from a set of potential comparison units that are not necessarily drawn from the same population as the treated units, but for whom the observable characteristics, $X_{i}$, match those of the treated units up to some selected degree of closeness. More precisely, the propensity score allows us to correct the estimation of the treatment effect, controlling for the existence of these confounding factors, based on the idea that bias is reduced when the comparison of outcomes is performed using treated and control subjects that are as similar as possible to one another.

The propensity score is defined by Rosenbaum and Rubin (1983) as the conditional probability of receiving a treatment given pre-treatment characteristics: 


$$
p(X) \equiv P\{D=1 \mid X\}=E\{D \mid X\}
$$

where $D=\{0,1\}$ indicates whether the agent is treated or not, and $X$ is a vector of pre-treatment characteristics. Now, let us consider a population of individuals denoted by $i$. If the propensity score $p\left(X_{i}\right)$ is known, then the Average Treatment Effect on the Treated (ATT) can be estimated as follows,

$$
\begin{aligned}
& \tau=E\left\{Y_{1 i}-Y_{0 i} \mid D_{i}=1\right. \\
& =E\left\{E\left\{Y_{1 i}-Y_{0 i} \mid D_{i}=1 p\left(X_{i}\right)\right\}\right\} \\
& =E\left\{E \left\{Y_{1 i} \mid D_{i}=1 p\left(X_{i}\right\}-E\left\{Y_{0 i}\left|D_{i}=0 p\left(X_{i}\right)\right| D_{i}=1\right.\right.\right.
\end{aligned}
$$

where $Y_{1 i}$ and $Y_{1 i}$ are the potential outcomes in the two counterfactual situations of treatment and no treatment.

Some hypothesis need to be made in order to derive Equation 2 given Equation I. First is the balancing of pre-treatment variables given the propensity score,

$$
D \perp X \mid p(X)
$$

We aso need to assume that assignment to the treatment is unconfounded,

$$
Y_{1}, Y_{0} \perp D \mid X
$$

Thus, the assignment to the treatment is unconfounded given the propensity score,

$$
Y_{1}, Y_{0} \perp D \mid p(X)
$$

It is important to note that the second hypothesis about unconfoundness cannot be tested. However, the first hypothesis about balancing can be verified. If Equation 3 is satisfied, then, for a given propensity score, exposure to the treatment is random and therefore treated and control groups should be on average observationally identical. Hence, any standard probability model can be adopted to estimate the propensity score. 


\subsection{Identification of the Model}

As Becker and Ichino (2002) argued, the propensity score is estimated according to the following process:

I. Estimate a probit model of the likelihood of marriage,

$$
P\left\{D_{i}=1 \mid X_{i}\right\}=\Phi\left(h\left(X_{i}\right)\right.
$$

where $\Phi$ is the normal (logistic) c.d.f. and $h\left(X_{i}\right)$ represents the vector of covariates that determine the treatment (the decision to marry between I998 and 2006).

More precisely, I run the following logistic regression,

$$
y_{i t}=\beta X_{t}+\delta Z_{i(t-)}+\varepsilon_{t}
$$

where $y_{i t}$ is a dummy variable that equals one if the woman married between 1998 and 2006 and zero otherwise. $X_{i t}$ is a vector of explanatory variables at date $t$ (2006) that determine the probability of marriage, such as age, level of education, and region of residence. $Z_{i(t-) 1}$ is vector of lagged variables at date $t^{-}$I (I998), such as the woman's work status and the wealth of her parental household. The latter is used because all women in my sample were single in 1998 and were then living in their parental household. $\varepsilon_{i t}$ represents the error term that follows a normal distribution $N:(0, \sigma)$.

2. I split the sample into $k$ equally spaced intervals of the propensity score $(k=5)$.

3. Within each interval, I test for the similarity between the average propensity scores of the treated and the control groups. The test is repeated until, under all alternatives, the average propensity score of treated and control units do not differ.

4. Within each interval, the means of each characteristic should not differ between treated and control units. This is a necessary condition for the balancing hypothesis.

\subsection{The Average Treatment Effect on the Treated}

The estimation of the propensity score is not enough to estimate the ATT using Equation 2. The reason is that the probability of observing two units with exactly the same propensity score is almost zero since $p(X)$ is a continuous variable. To solve this problem, different methods have 
been proposed in the literature such as nearest neighbor matching, radius matching, and kernel matching. These methods reach different points on the frontier of the tradeoff between quality and quantity of the matches. However, none of them is a priori better than the others.

In the present research, I opt for the nearest neighbor method to match treated and control groups. The nearest neighbor method is an easy method that allows the comparison of the matched variables of the simulated control group with those of the intervention group. This method consists of looking for the closest propensity score in the control group to the propensity score of each woman in the treated group, and matching these cases to one another. Note that a woman in the control group can be the best match for more than one woman in the treated group.After matching, the difference between the outcome of the treated women and those of the matched control women is computed. Then, the ATT can be obtained by averaging these differences, although, some of these matches can be poor since the nearest neighbor may have a very different propensity score.

Let us denote the treated group (e.g. the women who got married between 1998 and 2006) by $T$ and the control group (e.g. the women who remained single during the entire period) by $C . Y_{i}^{T}$ and $Y_{j}^{C}$ represent the observed outcomes of the treated and control groups respectively. The nearest neighbor matching can then be represented as,

$$
C(i)=\min _{j} \mathrm{P} p_{i}-p_{j} \mathrm{P}
$$

where $C(i)$ is the set of the control women matched to the treated women $i$ with an estimated value of the propensity score of $p_{i}$.

Equation 8 could be a single match or a set of multiple nearest neighbors. Note that the latter is rarely used, in particular, if the characteristics $X$ contains continuous variables; the likelihood of multiple nearest neighbors is furtherreducedifthepropensityscoreisestimated(Beckerand Ichino;2002).

The number of controls matched with observation $i \in T$ is denoted by $N_{i}^{C}$ and the weights are defined by $w_{i j}=\frac{1}{N_{i}^{C}}$ if $j \in C(i)$ and $w_{i j}=0$ otherwise. The formula can then be written as follows, 


$$
\begin{aligned}
& \tau^{M}=\frac{1}{N^{T}} \sum_{i \in T}\left[Y_{i}^{T}-\sum_{j \in C(i)} w_{j} Y_{j}^{C}\right] \\
& =\frac{1}{N^{T}}\left[\sum_{i \in T} Y_{i}^{T}-\sum_{i \in T} \sum_{j \in C(i)} w_{j} Y_{j}^{C}\right] \\
& =\frac{1}{N^{T}} \sum_{i \in T} Y_{i}^{T}-\frac{1}{N^{T}} \sum_{j \in C} w_{j} Y_{j}^{C}
\end{aligned}
$$

where $\mathrm{M}$ stands for the nearest neighbor matching and $N^{T}$ represents the number of women in the treated group. The weights $w_{j}$ are defined by $w_{j}=\sum_{i} w_{j}$.

We now turn our attention to the variances of these estimates. To derive these variances, the weights are assumed to be fixed and the outcomes are assumed to be independent across women.

$$
\begin{array}{r}
\operatorname{Var}\left(\tau^{M}\right)=\frac{1}{\left(N^{T}\right)^{2}}\left[\sum_{i \in T} \operatorname{Var}\left(Y_{i}^{T}\right)+\sum_{j \in C}\left(w_{j}\right)^{2} \operatorname{Var}\left(Y_{j}^{C}\right]\right. \\
=\frac{1}{\left(N^{T}\right)^{2}}\left[N^{T} \operatorname{Var}\left(Y_{i}^{T}\right)+\sum_{j \in C}\left(w_{j}\right)^{2} \operatorname{Var}\left(Y_{j}^{C}\right]\right. \\
=\frac{1}{N^{T}} \operatorname{Var}\left(Y_{i}^{T}\right)+\frac{1}{\left(N^{T}\right)^{2}} \sum_{j \in C}\left(w_{j}\right)^{2} \operatorname{Var}\left(Y_{j}^{C}\right)
\end{array}
$$

"Note that, to save on computing time, nearest neighbors are not determined by comparing treated observations to every single control, but by first sorting all records by the estimated propensity score and then searching for the closest control unit(s)" (see Becker ad Ichino; 2002).

\section{Empirical Results}

This section presents the empirical results of the propensity score matching model. For the sake of robustness checking, I have tested different matching methods, including the single nearest neighbor, the five nearest neighbor and kernel matching. Sensitivity analysis shows that the results are quite robust. Since the results are very similar for all these methods, only those of the single nearest neighbor are analyzed in the present section. The results of the other matching methods are presented in detail in Appendix B. 
A total sample of I,I44 women is used to estimate the model. As described above, these women have been selected based on particular criteria. Now, turning our attention to the two subgroups, 4I percent of the sample are treated versus 5i percent control.

To obtain the results presented here, I first started by estimating a model of selection into marriage (a probit model) that allows the estimation of a propensity score for each woman in the sample. Using this propensity score, each treated woman searches forward and backward for her match in the control group (using either a single or a five nearest neighbor or other matching method). Before calling the matching process, the data was randomly sorted and, interestingly, observations with identical propensity score values have been observed. In addition, with regards to the matching results, 674 of 675 treated units have been matched.

The following tables display the results obtained, specifically, those of the Average Treatment Effect on the Treated (ATT) as well as the Average Treatment Effect (ATE) and the Average Treatment Effect on the Untreated (ATU). Two outcomes are considered. On the one hand, I aim to identify the effect of marriage on market labor supply. On the other hand, the treatment effect on domestic labor supply is identified.

Table 11: Variable means and standard deviations by marital status

\begin{tabular}{|l|c|c|c|c|c|c|c|c|c|}
\hline & \multicolumn{3}{|c|}{ Single } & \multicolumn{3}{c|}{ Married } & \multicolumn{3}{c|}{ All } \\
\hline Variables & N & Mean & $\begin{array}{c}\text { Sd. } \\
\text { dev. }\end{array}$ & N & Mean & $\begin{array}{c}\text { Sd. } \\
\text { dev. }\end{array}$ & N & Mean & $\begin{array}{c}\text { Sd. } \\
\text { dev. }\end{array}$ \\
\hline In 1998 & & & & & & & & & \\
\hline Age & 469 & 20.49 & 4.78 & 675 & 19.99 & 3.43 & 1144 & 20.19 & 4.04 \\
\hline Age at marriage & - & - & - & 675 & 23.49 & 3.64 & 675 & 23.49 & 3.64 \\
\hline Market labor supply & 54 & 11.72 & 7.95 & 110 & 10.74 & 6.58 & 164 & 11.06 & 7.05 \\
\hline Domestic labor supply & 469 & 18.79 & 17.65 & 675 & 23.48 & 16.97 & 1144 & 21.56 & 17.4 \\
\hline $\begin{array}{l}\text { Nbr. of children in } \\
\text { household }\end{array}$ & - & - & - & - & - & - & - & - & - \\
\hline $\begin{array}{l}\text { Dummy for market } \\
\text { work }\end{array}$ & 469 & 0.17 & 0.37 & 675 & 0.15 & 0.35 & 1144 & 0.15 & 0.36 \\
\hline Low household wealth & 469 & 0.84 & 0.36 & 675 & 0.86 & 0.34 & 1144 & 0.85 & 0.35 \\
\hline High household wealth & 469 & 0.16 & 0.36 & 675 & 0.14 & 0.34 & 1144 & 0.15 & 0.35 \\
\hline Household size & 469 & 6.36 & 2.69 & 675 & 6.56 & 2.82 & 1144 & 6.48 & 2.77 \\
\hline In 2006 & & & & & & & & & \\
\hline
\end{tabular}




\begin{tabular}{|l|c|c|c|c|c|c|c|c|c|}
\hline Age & 469 & 27.55 & 4.9 & 675 & 27.09 & 3.52 & 1144 & 27.28 & 4.15 \\
\hline Market labor supply & 166 & 45.6 & 12.5 & 121 & 41.04 & 10.78 & 287 & 43.68 & 12 \\
\hline Domestic labor supply & 469 & 21.65 & 17.8 & 675 & 52.22 & 31.6 & 1144 & 39,69 & 30.74 \\
\hline Father's education & 160 & 3.06 & 2.31 & 664 & 2.9 & 2.23 & 824 & 2.93 & 2.25 \\
\hline Mother's education & 59 & 1.53 & 1.29 & 655 & 1.98 & 1.8 & 714 & 1.94 & 1.77 \\
\hline $\begin{array}{l}\text { Nbr. of children in } \\
\text { household }\end{array}$ & - & - & - & 675 & 1.35 & 0.86 & 675 & 1.35 & 0.86 \\
\hline $\begin{array}{l}\text { Dummy for market } \\
\text { work }\end{array}$ & 469 & 0.35 & 0.48 & 675 & 0.17 & 0.38 & 1144 & 0.25 & 0.43 \\
\hline Illiterate & 469 & 0.08 & 0.27 & 675 & 0.09 & 0.29 & 1144 & 0.09 & 0.28 \\
\hline $\begin{array}{l}\text { Less than intermediate } \\
\text { educ. }\end{array}$ & 469 & 0.12 & 0.32 & 675 & 0.13 & 0.34 & 1144 & 0.13 & 0.33 \\
\hline $\begin{array}{l}\text { General intermediate } \\
\text { education }\end{array}$ & 469 & 0.01 & 0.09 & 675 & 0.01 & 0.12 & 1144 & 0.01 & 0.11 \\
\hline $\begin{array}{l}\text { Technical intermediate } \\
\text { educ. }\end{array}$ & 469 & 0.3 & 0.46 & 675 & 0.39 & 0.49 & 1144 & 0.35 & 0.48 \\
\hline $\begin{array}{l}\text { Above intermediate } \\
\text { education }\end{array}$ & 469 & 0.07 & 0.25 & 675 & 0.06 & 0.24 & 1144 & 0.06 & 0.25 \\
\hline University education & 469 & 0.36 & 0.48 & 675 & 0.29 & 0.45 & 1144 & 0.32 & 0.47 \\
\hline Household size & 469 & 5.3 & 2.18 & 675 & 3.55 & 1.37 & 1144 & 4.27 & 1.95 \\
\hline Cairo & 469 & 0.21 & 0.41 & 675 & 0.15 & 0.36 & 1144 & 0.17 & 0.38 \\
\hline Alexandria & 469 & 0.16 & 0.36 & 675 & 0.15 & 0.36 & 1144 & 0.15 & 0.36 \\
\hline Urban lower regions & 469 & 0.19 & 0.39 & 675 & 0.15 & 0.35 & 1144 & 0.16 & 0.37 \\
\hline Urban upper regions & 469 & 0.2 & 0.4 & 675 & 0.19 & 0.39 & 1144 & 0.19 & 0.39 \\
\hline Rural lower regions & 469 & 0.13 & 0.33 & 675 & 0.22 & 0.42 & 1144 & 0.18 & 0.39 \\
\hline Rural lower regions & 469 & 0.12 & 0.32 & 675 & 0.15 & 0.35 & 1144 & 0.13 & 0.34 \\
\hline $\begin{array}{l}\text { Basic services in } \\
\text { household }\end{array}$ & 469 & 3.12 & 1.25 & 675 & 3 & 1 & 1144 & 2.86 & 1.17 \\
\hline
\end{tabular}

Source: Author's calculations using the ELMS of 1998 and 2006.

Table I2 presents the results of the selection into the treatment model, i.e, the selection into marriage model (which corresponds to women who got married between 1998 and 2006). Clearly, the probability of being treated increases with the level of education. In other words, females with a less than intermediate level of education, as well as those having a general intermediate level of education, had higher probabilities of getting married between 1998 and 2006 relative to their illiterate peers. The model also 
controls for age, working status in 1998 and parental household wealth in 1998. The probability of marriage increases with age and decreases with the parental wealth.

Table 12: Treatment selection: Model 1

\begin{tabular}{|l|c|c|c|}
\hline & Coefficient & Std. Err. & T. Stat. \\
\hline Age & $0.641^{* * *}$ & 0.101 & 6.31 \\
\hline Age squared & $-0.010^{* * *}$ & 0.002 & -6.45 \\
\hline $\begin{array}{l}\text { Less than intermediate } \\
\text { education }\end{array}$ & $0.256^{* *}$ & 0.155 & 1.65 \\
\hline General intermediate education & $0.651^{* *}$ & 0.375 & 1.73 \\
\hline Technical intermediate education & $0.336^{* * *}$ & 0.130 & 2.58 \\
\hline Above intermediate education & 0.131 & 0.189 & 0.69 \\
\hline University education & 0.102 & 0.141 & 0.72 \\
\hline Market work in 1998 & -0.025 & 0.117 & -0.21 \\
\hline Household Wealth in 1998: High & $-0.132^{* * *}$ & 0.048 & -2.73 \\
\hline Constant & $-9.139 * * *$ & 1.492 & -6.12 \\
\hline Log Likelihood & -736.588 & & \\
\hline Pseudo R2 & 0.049 & & \\
\hline Prob > chi2 & 0.000 & & \\
\hline Nbr. of Observations & 1140.000 & & \\
\hline
\end{tabular}

Note: i. Dependent variable is a binary variable that is equal to one if the woman married between 1998 and 2006 and, equal to zero if the female remained single at least until 2006.

ii. ${ }^{* * *}$ statistically significant at the $1 \%$ level, ${ }^{* *}$ statistically significant at the $5 \%$ level,

${ }^{*}$ statistically significant at the $10 \%$ level.

iii. The reference level of education is illiterate.

Source: Author's calculations.

In Table 13, we observe the distribution of the propensity score (PS). The mean of the PS is of 0.591 with a variance of 0.013 .

Table 13: Propensity score distribution: Model 1

\begin{tabular}{|l|c|c|l|l|}
\hline & Percentiles & $\operatorname{Pr}$ (Treated) & & \\
\hline $1 \%$ & 0.156 & 0.072 & & \\
\hline $5 \%$ & 0.381 & 0.073 & Mean & 0.591 \\
\hline
\end{tabular}




\begin{tabular}{|l|c|c|c|c|}
\hline $10 \%$ & 0.445 & 0.078 & Std. Deviation & 0.117 \\
\hline $25 \%$ & 0.539 & 0.078 & & \\
\hline $50 \%$ & 0.604 & & Variance & 0.013 \\
\hline $75 \%$ & 0.672 & 0.807 & Skewness & -1.266 \\
\hline $90 \%$ & 0.723 & 0.812 & Kurtosis & 5.839 \\
\hline $95 \%$ & 0.749 & 0.82 & & 1140 \\
\hline $99 \%$ & 0.779 & 0.821 & $\mathrm{~N}$ & \\
\hline
\end{tabular}

Source: Author's calculations.

Turning to the results of the matching, Table I4 shows the matching estimates for the two outcomes, these being the domestic and market labor supplies. ${ }^{.}$Results of the Average Treatment Effect (ATE) show the difference-in-difference in outcomes. In other words, the ATE shows the difference between the treated and the untreated women. Compared to untreated units, treated women spent on average about 30.079 hours more on domestic work and 7.55 I hours less on market work. The Average Treatment Effect on the Treated (ATT) equals $3 \mathrm{I} .442$ and -8.667 for the domestic and market labor supplies respectively.

Table 14: Matching estimates: Model 1

\begin{tabular}{|l|c|c|c|c|c|}
\hline $\begin{array}{l}\text { Hours spent on } \\
\text { domestic work }\end{array}$ & Treated & Controls & Difference & S.E. & T. Stat. \\
\hline ATT & 52.231 & 20.789 & 31.442 & 1.797 & 17.5 \\
\hline ATU & 21.672 & 49.781 & 28.109 & & \\
\hline ATE & & & 30.079 & & \\
\hline $\begin{array}{l}\text { Hours spent on } \\
\text { market work }\end{array}$ & Treated & Controls & Difference & S.E. & T. Stat. \\
\hline ATT & 7.368 & 16.037 & -8.667 & 1.824 & -4.75 \\
\hline ATU & 16.208 & 10.275 & -5.933 & & \\
\hline ATE & & & -7.551 & & \\
\hline
\end{tabular}

Notes: i. These are the results of the single nearest neighbor matching.

ii. ATT is the Average Treatment Effect on the Treated, ATU is the Average Treatment Effect on the Untreated and ATE is the Average Treatment Effect.

iii. Number of treated: 674 . Number of controls: 466 .

Source: Author's calculations.

1 These are number of weekly hours. 
These results seem to confirm our hypothesis that marriage explains an important part of the low female market labor force participation in Egypt. Again, Egyptian married females need a more equitable allocation of domestic activities within their own households, as well as more efficient family-friendly policies in the labor market.

A second specification of the selection equation is presented in Table 15. Compared to Table i2, we observe that the value of the Pseudo R-squared is significantly higher using the second specification; 0.183 and 0.049 respectively for the Models 2 and I. In Table 15 , I also control for the region of residence as well as for the parent's level of education. Living in Cairo significantly decreases the probability of getting married between 1998 and 2006 by 25.3 percent. In addition, parental education, in particular the mother's education, clearly affects the probability of marriage.

Table 15: Treatment selection: Model 2

\begin{tabular}{|l|c|c|c|}
\hline & Coefficient & Std. Err. & T. Stat. \\
\hline Age & $0.534^{* * *}$ & 0.107 & 4.99 \\
\hline Age squared & $-0.009^{* * *}$ & 0.002 & -5.10 \\
\hline Less than intermediate education & $0.269^{* *}$ & 0.158 & 1.70 \\
\hline General intermediate education & $0.551^{*}$ & 0.392 & 1.40 \\
\hline Technical intermediate education & $0.324^{* *}$ & 0.134 & 2.41 \\
\hline Above intermediate education & $0.048^{*}$ & 0.201 & 0.24 \\
\hline University education & $-0.155^{* *}$ & 0.149 & -1.04 \\
\hline Living in Cairo & $-0.253^{* *}$ & 0.119 & -2.13 \\
\hline Mother's education 2 & $1.544^{* * *}$ & 0.306 & 5.05 \\
\hline Mother's education 3 & $1.942^{* * *}$ & 0.348 & 5.57 \\
\hline Mother's education 4 & $2.093^{* * *}$ & 0.519 & 4.03 \\
\hline Father's education 2 & $0.799^{* * *}$ & 0.152 & 5.25 \\
\hline Father's education 3 & $0.774^{* * *}$ & 0.159 & 4.88 \\
\hline Father's education 4 & $0.325^{*}$ & 0.236 & 1.38 \\
\hline Market work in 1998 & -0.012 & 0.124 & -0.10 \\
\hline High HH wealth in 1998 & $-0.306^{* * *}$ & 0.056 & -5.46 \\
\hline Constant & $-7.823^{* * *}$ & 1.576 & -4.96 \\
\hline Log likelihood & -630.138 & & \\
\hline
\end{tabular}




\begin{tabular}{|l|c|l|l|}
\hline Pseudo R2 & 0.183 & & \\
\hline Prob $>$ chi2 & 0.000 & & \\
\hline Nbr. of Observations & 1140.000 & & \\
\hline
\end{tabular}

Notes: i. Cairo is a dummy variable equal to 1 if the woman is living in Cairo and zero otherwise.

ii. The reference group for the parental level of education is illiterate.

iii. Mother/father's education 2 is less than intermediate education. Mother/father's education 3 is

intermediate education. Mother/father's education 4 is above than intermediate. The reference here is illiterate.

iv. ${ }^{* * *}$ statistically significant at the $1 \%$ level, ${ }^{* *}$ statistically significant at the $5 \%$ level,

${ }^{*}$ statistically significant at the $10 \%$ level.

Source: Author's calculations.

Again, Tables 16 and 17 show, respectively, the distribution of the PS and the matching results for the second specification (Model 2). For the domestic labor supply as an output, the ATT is 25.797 with a T statistic of 8.45. The ATE equals 28.583. Then, controlling for more variables in the second specification not only allows for an improvement in the model's quality, but also modifies the matching results. Turning our analysis to the

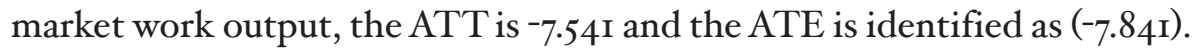

Table 16: Propensity score distribution: Model 2

\begin{tabular}{|l|c|c|c|c|}
\hline & Percentiles & $\operatorname{Pr}$ (Treated) & & \\
\hline $1 \%$ & 0.099 & 0.025 & & \\
\hline $5 \%$ & 0.211 & 0.031 & Mean & 0.591 \\
\hline $10 \%$ & 0.276 & 0.052 & Std. Deviation & 0.227 \\
\hline $25 \%$ & 0.439 & 0.056 & & \\
\hline $50 \%$ & 0.590 & & Variance & 0.052 \\
\hline $75 \%$ & 0.744 & 0.998 & Skewness & -0.021 \\
\hline $90 \%$ & 0.942 & 0.998 & Kurtosis & 2.342 \\
\hline $95 \%$ & 0.979 & 0.999 & & 1140 \\
\hline $99 \%$ & 0.995 & 0.999 & $N$ & \\
\hline
\end{tabular}

Source: Author's calculations. 
Table 17: Matching estimates: Model 2

\begin{tabular}{|l|c|c|c|c|c|}
\hline $\begin{array}{l}\text { Hours spent on domestic } \\
\text { work }\end{array}$ & Treated & Controls & Difference & S.E. & T. Stat. \\
\hline ATT & 52.231 & 26.435 & 25.797 & 3.054 & 8.45 \\
\hline ATU & 21.672 & 54.285 & 32.614 & & \\
\hline ATE & & & 28.583 & & \\
\hline $\begin{array}{l}\text { Hours spent on market } \\
\text { work }\end{array}$ & Treated & Controls & Difference & S.E. & T. Stat. \\
\hline ATT & 7.468 & 14.909 & -7.541 & 3.642 & -2.07 \\
\hline ATU & 16.208 & 7.933 & -8.275 & & \\
\hline ATE & & & -7.841 & & \\
\hline
\end{tabular}

Note: These are the results of the single nearest neighbor matching.

Source: Author's calculations.

A third specification of the selection into marriage model was tested. This model only differs in the regions' distinction. Instead of controlling for only one dummy for region that equals $\mathrm{I}$ if the woman lives in Cairo and zero otherwise, I distinguish between five different regions. The results of Model 3 are presented in Tables I8, I9 and 20. Interestingly, the Average Treatment Effect (ATE) for market labor supply is -I2.978 weekly hours, and, it equals 27.47 for the domestic labor supply.

Table 18: Treatment selection: Model 3

\begin{tabular}{|l|c|c|c|}
\hline & Coefficient & Std. Err. & T. Stat. \\
\hline Age & $0.536^{* * *}$ & 0.108 & 4.96 \\
\hline Age square & $-0.009^{* * *}$ & 0.002 & -5.05 \\
\hline Less than intermediate education & $0.286^{* *}$ & 0.161 & 1.78 \\
\hline General intermediate education & 0.511 & 0.395 & 1.29 \\
\hline Technical intermediate education & $0.354^{* * *}$ & 0.136 & 2.60 \\
\hline Above intermediate education & 0.109 & 0.203 & 0.54 \\
\hline University education & -0.109 & 0.151 & -0.72 \\
\hline Urban lower Region & -0.050 & 0.126 & -0.40 \\
\hline Urban upper Region & 0.001 & 0.122 & 0.01 \\
\hline Rural lower Region & $0.457^{* * *}$ & 0.130 & 3.51 \\
\hline
\end{tabular}




\begin{tabular}{|l|c|c|c|}
\hline Rural upper Region & $0.237^{*}$ & 0.147 & 1.61 \\
\hline Mother's education 2 & $1.469^{* * *}$ & 0.301 & 4.88 \\
\hline Mother's education 3 & $1.945^{* * *}$ & 0.349 & 5.56 \\
\hline Mother's education 4 & $2.057^{* * *}$ & 0.511 & 4.03 \\
\hline Father's education 2 & $0.848^{* * *}$ & 0.154 & 5.52 \\
\hline Father's education 3 & $0.778^{* * *}$ & 0.160 & 4.86 \\
\hline Father's education 4 & 0.311 & 0.237 & 1.31 \\
\hline Market work in 1998 & -0.048 & 0.125 & -0.39 \\
\hline High HH Wealth in 1998 & $-0.272^{* * *}$ & 0.059 & -4.61 \\
\hline Constant & $-8.061^{* * *}$ & 1.599 & -5.04 \\
\hline Log likelihood & -623.453 & & \\
\hline Pseudo R2 & 0.191 & & \\
\hline Prob > chi2 & 0.000 & & \\
\hline N & 1140.000 & & \\
\hline
\end{tabular}

Notes: i. The reference category for region is Cairo and Alexandria.

ii. ${ }^{* * *}$ statistically significant at the $1 \%$ level, ${ }^{* *}$ statistically significant at the $5 \%$ level, ${ }^{*}$ statistically significant at the $10 \%$ level.

Source: Author's calculations.

Table 19: Propensity score distribution: Model 3

\begin{tabular}{|c|c|c|c|c|}
\hline & Percentiles & $\operatorname{Pr}$ (Treated) & & \\
\hline $1 \%$ & 0.112 & 0.034 & & \\
\hline $5 \%$ & 0.208 & 0.043 & Mean & 0.591 \\
\hline $10 \%$ & 0.266 & 0.044 & Std. Deviation & 0.234 \\
\hline $25 \%$ & 0.416 & 0.063 & & \\
\hline $50 \%$ & 0.591 & & Variance & 0.054 \\
\hline $75 \%$ & 0.758 & 0.997 & Skewness & -0.031 \\
\hline $90 \%$ & 0.946 & 0.998 & Kurtosis & 2.175 \\
\hline $95 \%$ & 0.980 & 0.998 & & 1140 \\
\hline $99 \%$ & 0.993 & 0.998 & $\mathrm{~N}$ & \\
\hline
\end{tabular}

Source: Author's calculations. 
Table 20: Matching estimates: Model 3

\begin{tabular}{|l|c|c|c|c|c|}
\hline $\begin{array}{l}\text { Hours spent on } \\
\text { domestic work }\end{array}$ & Treated & Controls & Difference & S.E. & T. Stat. \\
\hline ATT & 52.231 & 24.09 & 28.141 & 3.047 & 9.23 \\
\hline ATU & 21.672 & 48.182 & 26.511 & & \\
\hline ATE & & & 27.47 & & \\
\hline $\begin{array}{l}\text { Hours spent on } \\
\text { market work }\end{array}$ & Treated & Controls & Difference & S.E. & T-stat. \\
\hline ATT & 7.368 & 22.133 & -14.765 & 3.612 & -4.09 \\
\hline ATU & 16.208 & 5.815 & -10.392 & & \\
\hline ATE & & & -12.978 & & \\
\hline
\end{tabular}

Note: These are the results of the single nearest neighbor matching.

Source: Author's calculations.

\section{Conclusions}

We have plenty of information and studies on the time that women spend in the labor market, but none on the submerged part of their time spent at home. Economists have made a huge effort to explain the market behavior of married women, such as, their patterns of participation, the number of hours worked, the determinants of wives earnings, occupational choice, and the gender wage differential. Although the present research is the first to analyze the allocation of time within the home sector, this allocation may have an impact on the well-being of the family that is no less important than changes in women's working haIt seems quite difficult to detect the effect of policy measures on actual individual behavior, especially with regards to work, child care and housekeeping. It is necessary, however, to calculate how much time is spent on each of the above activities. No money is involved in work like cooking, taking care of the children or house cleaning, though much time is needed for this kind of work. If women have to pay for the value of domestic work in order to reconcile family and working life, the risk that they will leave their labor market position as well as their independent incomes becomes higher.

Thus, Egypt, as most developing and developed countries, needs many regulation reforms to reduce the persistent gender bias in intrahousehold division of labor. For this, policies that support women's access to productive employment, with equal wages for equal jobs, taking full account of the burden of women's family and household responsibilities, 
strongly need to be considered. An example of such kinds of jobs could be part-time jobs and also the supply of day care for children.

We expect the results of this study to be of great importance to policymakers and non-governmental organizations, especially when designing family policies. More specifically, effective public policies are needed to actively support the role of the family, i.e. of women, to substitute for the lacking welfare state to affect the division of paid and unpaid work. Policies affecting not only women's participation in the labor force but also people's attitudes towards the division of paid and unpaid work are needed. It turns out that the existing policies in Egypt are not sufficient in this respect.

This study aims at identifying how selection into marriage alters the time allocation of women. The objective is then to explore this new area of research in Egypt in order to gain insight into policy measures that can effectively influence women's time allocation. A matching model is estimated to identify how selection into marriage alters the time allocation of women. The empirical results show that marriage significantly affects both types of work. Married women spend weekly about eight hours less on market work relative to their single counterparts. And, interestingly, marriage as a treatment increases the domestic labor supply by thirty hours weekly on average.

More effective policies in Egypt would thus allow not only for the increase of women's participation in paid work, but also a more equitable division of labor within families. Best practice arrangements could be: employee sovereignty over working times, equal access to productive employment with equal wages for equal jobs (for men and women), promotion and benefits, and the reconciliation of paid work and family life. It is surely important to find appropriate forms of intervention for supporting the family, which should include financial support for beneficiaries, without undermining the structure of family life. Organized voluntarism could also play an important role, while informal networks, which have traditionally sustained the family, should be reinforced. 


\section{References}

Abadie Alberto, and Guido W. Imbens. 2002. "Simple and Bias Corrected Matching Estimators for Average Treatment Effects." NEBR Technical Working paper 0283, National Bureau of Economic Research.

Anxo Dominique, and Paul S. Carlin. 2004. "Intra-Family Allocation to Housework: French Evidence." Electronic International fournal of Time Use Research I (July): 14-36.

Apps Patricia, and Ray Rees. 1997. "Collective Labor Supply and Household Production." Journal of Political Economy IO5(February): I78-ı90.

Apps Patricia. 2004. "Gender, Time use and Models of the Household." Policy Research Working paper 3233, The World Bank.

Apps Patricia, and Ray Rees. 2005. "Gender, Time Use and Public Policy Over the Life Cycle." Oxford Reviere of Economic Policy 2I (Autumn): 439-46r.

Assaad Ragui. 2007. "Labour Supply, Employment and Unemployment in the Egyptian Economy: 1988-2006." Working paper 070I, Population Council.

Assaad Ragui, and Melanie Arntz. 2005. "Constrained Geographical Mobility and Gendered Labor Market Outcomes Under Structural

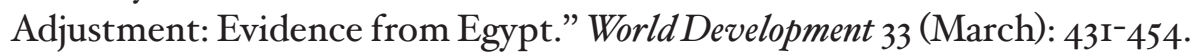

Assaad Ragui, and Fatma El-Hamidi. 20or. "Is All Work the Same? A Comparison of the Determinants of Female Participation and Hours of Work in Various Employment States in Egypt." Research in Middle East Economics 4. The Economics of Women and Work in the Middle East and North Africa. eds. Elsevier Science B.V., Mine Cinar, Netherlands.

Assaad Ragui and Fatma El-Hamidi. 2009. "Women in the Egyptian Labor Market: An Analysis of Developments, 1988-2006." In the Egyptian Labor Market Revisited, ed. Ragui Assaad: II7-156. American University in Cairo Press.

Barsoum Ghada. 2007. "Egypt Labor Market Panel Survey 2006: Report on Methodology and Data Collection.” Working paper 0704, Economic Research Forum.

Baxter Janeen. 1997. "Gender Equality and Participation in Housework: A Cross-National Perspective.” Fournal of Comparative Studies 28:220-247.

Becker Gary S.. 1976. The Economic Approach to Human Behavior. Chicago and London, University of Chicago Press.

Becker Gary S.. 1981. A Treatise on the Family. 2nd edition. Cambridge, MA: Harvard University Press. 
Berk Richard A., and Sarah Fenstermaker Berk . 1979. Labor and Leisure at Home: The Content and Organization of the Household Day. Beverly Hills, California, Sage Publications.

Brimes Julie. 1994. "Economic Dependency, Gender and the Division of Labor at Home." American fournal of Sociology roo (November): 652-688.

Coltranes Scott. 1996. Family Man: Fatherhood, Housework, and Gender Equity. New York, Oxford University Press.

Coltranes Scott. 2000. "Research on Household Labor: Modeling and Measuring the Social Embeddness of Routine Family Work." fournal of Marriage and the Family 62: 1208-1233.

Couprie Hélène. 2007. "Time Allocation Within the Family: Welfare Implications of Life in a Couple." The Economic fournal II7: 287-305.

Chiappori Pierre-André. 1997. "Introducing Household Production in Collective Models of Labor Supply." Fournal of Political Economy 105: 191209.

Demo David H., and Alan C. Acock. 1993. "Family Diversity and the Division of Domestic Labor: How Much Have Things Really Changed?." Family Relations 42: 323-331.

Donahoe Debra Anne. 1999. "Measuring Women's Work in Developing Countries." Population and Development Review 25: 543-576.

Donni Olivier. 2008. "Labor Supply, Home Production, and Welfare Comparisons." Fournal of Public Economics 92: 1720-1737.

Folbre Nancy. 1984. "Household Production in the Philippines: A Non-neoclassical Approach." Economic Development and Cultural Change, University of Chicago Press, vol. 32(2): 303-30, January.

Gerson Kathleen. 1986. Hard Choices. How Do Women Decide About Work, Career and Motherhood. California, The University of California Press.

Heckman James J., Hìdehiko Ichimura, and Petra Todd. I998. "Matching as an Econometric Evaluation Estimator." Review of Economic Studies 65: 26I-294.

Hersh Joni ,and Leslie S. Stratton. 1997. "Housework, Fixed Effects and Wages of Married Workers." Fournal of Human Resources 32: 285-307.

Hood Jane C.. 1983. Becoming a Tro-fob Family. New York, Praeger Publishers.

Hoodfar Homa. 1997. Between marriage and the market: Intimate politics and survival in Cairo. University of California Press.

Lundberg Shelly J.. 1988. "Labor Supply of Husbands and Wives: A Simultaneous Equation Approach." Review of Economics and Statistics 70: $224^{-235}$. 
Pencavel John. 1998. "The Market Work Behavior and Wages of Women: 1975-94." Fournal of Human Resources 4: 77I-804.

Presser Harriet B.. 1994. "Employment Schedules Among Dual-Earner Spouses and the Division of Household Labor by Gender." American Sociological Review 59: 348-364.

Rappoport Benoit, Catherine Sofer, and Anne Solaz. 2009. "Household Production in a Collective Model: Some New Results" Fournal of Population Economics. Forthcoming paper.

Roushdy Rania. 2004. "Intra Household Allocation in Egypt: Does Women's Empowerment Lead to Greater Investments in Children?.” Working paper 040I. Economic Research Forum.

Shaw Kathryn. 1994. "The Persistence of Female Labor Supply:Empirical Evidence and Implications." Fournal of Human Resources 29: 348-378.

Shelton Beth Anne. 1992. "Women Men and Time: Gender Differences in Paid Work, Housework and Leisure.” In Women's studies I27. New York, Greenwood Press. 


\section{Annex A: More About the Data}

\section{Time-use Data: Domestic Activities}

- Housework: washing dishes, doing laundry, cleaning house;

- Food and drink: raising poultry, producing butter/ cheese, cooking;

- Home maintenance: helping in construction work;

- Care activities: caring for the sick/ the elderly, taking care of children;

- Shopping for the household;

- Agriculture activities, collecting water, collecting firewood.

\section{Definitions}

The Market Definition of Labor Force "includes all females engaged in economic activities for purposes of market exchange." (Assaad and ElHamidi, 2009).

The Extended Definition of Labor Force " includes those engaged in the production and processing of primary products, whether for the market, for barter, or for their own consumption; the production of all other goods and services for the market; and, in the case of households that produce such goods and services for the market, the corresponding production for their own consumption. The extended definition includes many women engaged in animal husbandry and the processing of dairy of products for purposes of household consumption, in addition to those engaged in market activity." (Assaad and El-Hamidi, 2009).

Domestic Activities is defined as the unpaid work done to maintain family members and/or a home. In the present study, we distinguish between two categories of domestic work. The first category is "housework" and the second is "child care." In our data, "housework" includes agriculture activities, raising poultry, producing butter/cheese, cooking, washingdishes, doing laundry, cleaning house, collecting water, collecting firewood, helping in construction work, caring for the sick/ the elderly and shopping for the household. "Child care", represents the time spent taking care of children.

The Extra-Extended Definition of Labor Force includes those considered as working according to the market definition, the extended definition, or engaged in domestic activities.

Independent Workers All women with irregular wage jobs, household enterprise workers, and the self employed with no household members. 


\section{Annex B: Sensitivity Analysis}

\section{Results of the Five Nearest Neighbor Matching}

Table 21: Matching estimates using the five nearest neighbor method: Model 1

\begin{tabular}{|l|c|c|c|c|c|}
\hline $\begin{array}{l}\text { Hours spent on } \\
\text { domestic work }\end{array}$ & Treated & Controls & Difference & S.E. & T. Stat. \\
\hline ATT & 52.231 & 21.082 & 31.149 & 1.577 & 19.75 \\
\hline ATU & 21.672 & 49.404 & 27.733 & & \\
\hline ATE & & & 29.753 & & \\
\hline $\begin{array}{l}\text { Hours spent on } \\
\text { market work }\end{array}$ & Treated & Controls & Difference & S.E. & T. Stat. \\
\hline ATT & 7.368 & 17.025 & -9.657 & 1.441 & -6.70 \\
\hline ATU & 16.208 & 9.851 & -6.357 & & \\
\hline ATE & & & -8.308 & & \\
\hline
\end{tabular}

Notes: $i$. These are the results of the five nearest neighbor matching.

ii. The number of treated cases is 674 and the number of controls is 466 .

Source: Author's calculations.

Table 22: Matching estimates using the five nearest neighbor method: Model 2

\begin{tabular}{|l|c|c|c|c|c|}
\hline $\begin{array}{l}\text { Hours spent on } \\
\text { domestic work }\end{array}$ & Treated & Controls & Difference & S.E. & T. Stat. \\
\hline ATT & 52.231 & 24.242 & 27.989 & 2.241 & 12.49 \\
\hline ATU & $21 . .672$ & 54.18 & 32.508 & & \\
\hline ATE & & & 29.836 & & \\
\hline $\begin{array}{l}\text { Hours spent on market } \\
\text { work }\end{array}$ & Treated & Controls & Difference & S.E. & T. Stat. \\
\hline ATT & 7.368 & 17.983 & -10.615 & 2.536 & -4.19 \\
\hline ATU & 16.208 & 7.719 & -8.489 & & \\
\hline ATE & & & -9.746 & & \\
\hline
\end{tabular}

Notes: These are the results of the five nearest neighbor matching.

Source: Author's calculations. 
Table 23: Matching estimates using the five nearest neighbor method: Model 3

\begin{tabular}{|l|c|c|c|c|c|}
\hline $\begin{array}{l}\text { Hours spent on } \\
\text { domestic work }\end{array}$ & Treated & Controls & Difference & S.E. & T. Stat. \\
\hline ATT & 52.231 & 25.079 & 27.152 & 2.330 & 11.65 \\
\hline ATU & 21.672 & 52.443 & 30.771 & & \\
\hline ATE & & & 28.632 & & \\
\hline $\begin{array}{l}\text { Hours spent on } \\
\text { market work }\end{array}$ & Treated & Controls & Difference & S.E. & T. Stat. \\
\hline ATT & 7.368 & 16.019 & -8.651 & 2.589 & -3.34 \\
\hline ATU & 16.208 & 6.054 & -10.154 & & \\
\hline ATE & & & -9.265 & & \\
\hline
\end{tabular}

Note: These are the results of the five nearest neighbor matching.

Source: Author's calculations.

\section{Kernel Matching Results}

Table 24: Matching estimates using the kernel matching method: Model 1

\begin{tabular}{|l|c|c|c|c|c|}
\hline $\begin{array}{l}\text { Hours spent } \\
\text { on domestic } \\
\text { work }\end{array}$ & Treated & Controls & Difference & S.E. & T. Stat. \\
\hline ATT & 52.231 & 22.125 & 30.107 & 1.525 & 19.74 \\
\hline ATU & 21.619 & 50.347 & 28.727 & & \\
\hline ATE & & Controls & Difference & S.E. & T. Stat. \\
\hline $\begin{array}{l}\text { Hours spent } \\
\text { on market } \\
\text { work }\end{array}$ & Treated & 16.348 & -8.979 & 1.347 & -6.67 \\
\hline ATT & 7.368 & 9.796 & -6.427 & & \\
\hline ATU & 16.222 & & -7.94 & & \\
\hline ATE & & & & & \\
\hline
\end{tabular}

Note: These are kernel matching results.

Source: Author's calculations. 
Table 25: Matching estimates using the kernel matching method: Model 2

\begin{tabular}{|l|c|c|c|c|c|}
\hline $\begin{array}{l}\text { Hours spent } \\
\text { on domestic } \\
\text { work }\end{array}$ & Treated & Controls & Difference & S.E. & T. Stat. \\
\hline ATT & 52.231 & 24.861 & 27.369 & 2.33 & 11.74 \\
\hline ATU & 21.672 & 53.625 & 31.953 & & \\
\hline ATE & & Controls & Difference & S.E. & T. Stat. \\
\hline $\begin{array}{l}\text { Hours spent } \\
\text { on market } \\
\text { work }\end{array}$ & Treated & 16.75 & -9.382 & 2.648 & -3.54 \\
\hline ATT & 7.368 & 7.347 & -8.861 & & \\
\hline ATU & 16.208 & & -9.169 & & \\
\hline ATE & & & & & \\
\hline
\end{tabular}

Note: These are kernel matching results.

Source: Author's calculations.

Table 26: Matching estimates using the kernel matching method: Model 3

\begin{tabular}{|l|c|c|c|c|c|}
\hline $\begin{array}{l}\text { Hours spent } \\
\text { on domestic } \\
\text { work }\end{array}$ & Treated & Controls & Difference & S.E. & T-stat. \\
\hline ATT & 52.231 & 24.948 & 27.283 & 2.393 & 11.40 \\
\hline ATU & 21.672 & 51.826 & 30.154 & & \\
\hline ATE & & Controls & Difference & S.E. & T-stat. \\
\hline $\begin{array}{l}\text { Hours spent } \\
\text { on market } \\
\text { work }\end{array}$ & Treated & 16.952 & -9.585 & 2.739 & -3.50 \\
\hline ATT & 7.368 & 6.882 & -9.326 & & \\
\hline ATU & 16.208 & & -9.479 & & \\
\hline ATE & & & & & \\
\hline
\end{tabular}

Note: These are kernel matching results.

Source: Author's calculations. 


\section{Annex C: More On Labor Supply Determinants}

Table 27: Determinants of domestic labor supply

\begin{tabular}{|l|c|c|c|}
\hline & Single (16-64) & Married (16-64) & All \\
\hline & Coefficient & Coefficient & Coefficient \\
\hline Age in 2006 & $2,617^{* * *}$ & $1,412^{* * *}$ & $4,049^{* * *}$ \\
\hline Age squared in 2006 & $-0,034^{* * *}$ & $-0,023^{* * *}$ & $-0,047^{* * *}$ \\
\hline Age at marriage & - & $0,212^{* *}$ & - \\
\hline Household (HH) wealth in 1998 & $-1,360^{* * *}$ & $0,891^{* *}$ & $-1,009^{* * *}$ \\
\hline Basic Services in 2006 & $-0,641$ & $-0,753^{*}$ & $-1,622^{* * *}$ \\
\hline Less than intermediate education & $14,185^{* * *}$ & 1,349 & $7,925^{* * *}$ \\
\hline General intermediate education & 3,723 & $-0,802$ & $10,953^{* * *}$ \\
\hline Technical intermediate education & $8,473^{* * *}$ & 1,865 & $12,243^{* * *}$ \\
\hline Above intermediate education & $9,460^{* * *}$ & 2,141 & $12,764^{* * *}$ \\
\hline University education & $6,654^{* * *}$ & $-1,913$ & $9,463^{* * *}$ \\
\hline Nbr. of children in HH & $1,454^{*}$ & $4,890^{* * *}$ & $6,138^{* * *}$ \\
\hline Parent in the HH & - & $-30,323^{* * *}$ & $-24,164^{* * *}$ \\
\hline Sister/Bro. in law in HH & - & - & $-26,280^{* * *}$ \\
\hline Mother in law in HH & - & $-15,750$ & $-39,366^{* * *}$ \\
\hline Dummy for family project & 1,021 & $-1,559$ & $-0,891$ \\
\hline Urban regions & 0,667 & $-7,404^{* * *}$ & $-4,042^{* * *}$ \\
\hline Rural regions & $-0,551$ & $-4,176^{* * *}$ & $-1,887^{* * *}$ \\
\hline Constant & $-22,570^{* * *}$ & $22,121^{* * *}$ & $-41,202^{* * *}$ \\
\hline Sigma & 19,494 & 27,028 & 25,718 \\
\hline Log likelihood & $-6868,7003$ & $-18045,825$ & $-33284,573$ \\
\hline Pseudo R squared & 0,0188 & 0,0109 & 0,0626 \\
\hline N & 1835 & 3851 & 8554 \\
\hline
\end{tabular}

Notes: i. Tobit Results.

ii. Dependent variable: weekly hours spent on domestic work.

iii. The reference level of education is illiterate. The reference region is Cairo/ Alexandria.

Source: Author's calculations. 
Table 28: Determinants of market labor supply

\begin{tabular}{|l|c|c|c|}
\hline & Singles (16-64) & Married (16-64) & All \\
\hline & Coefficient & Coefficient & Coefficient \\
\hline Age in 2006 & $-0,350$ & 0,429 & 0,103 \\
\hline Age squared in 2006 & 0,003 & $-0,006^{*}$ & $-0,002$ \\
\hline Age at marriage & - & 0,097 & - \\
\hline Household (HH) wealth in 1998 & $-0,212$ & $-1,159^{* * *}$ & $0,368^{* * *}$ \\
\hline Basic Services in 2006 & $-0,510$ & $-0,120$ & $-0,026$ \\
\hline Less than intermediate education & $-1,542$ & $-0,387$ & $-0,016$ \\
\hline General intermediate education & 20,031 & $-3,974$ & 3,616 \\
\hline Technical intermediate education & 1,412 & $-1,896$ & $-2,061$ \\
\hline Above intermediate education & $-1,482$ & $-2,592$ & $-3,407^{* * *}$ \\
\hline University education & $-8,518^{* *}$ & $-1,659$ & $-4,390^{* * *}$ \\
\hline Nbr. of children in HH & 2,459 & $-0,517$ & $-1,053^{* * *}$ \\
\hline Parent in the HH & - & $-14,810$ & $-0,362$ \\
\hline Sister/Bro. in law in HH & - & - & $-6,277$ \\
\hline Mother in law in HH & - & - & $-20,724$ \\
\hline Dummy for family project & 0,637 & $1,305^{*}$ & $1,855^{* * *}$ \\
\hline Urban regions & $-3,816^{* *}$ & $-2,988^{* * *}$ & $-3,678^{* * *}$ \\
\hline Rural regions & $-8,665^{* * *}$ & $-4,823^{* * *}$ & $-6,308^{* * *}$ \\
\hline Constant & $67,175^{* * *}$ & $61,426^{* * *}$ & $62,4455^{* * *}$ \\
\hline Sigma & 13,104 & 11,787 & 12,939 \\
\hline Log likelihood & $-1244,3003$ & $-3681,4066$ & $-5886,6716$ \\
\hline Pseudo R squared & 0,0418 & 0,0253 & 0,0267 \\
\hline N & 313 & 948 & 1480 \\
\hline
\end{tabular}

Note: Tobit results.

Source: Author's calculations. bits. 

